Discussion Paper No. 14-047

Evidence on Book-tax Differences and Disclosure Quality Based on the Notes to the Financial Statements

Maria Theresia Evers, Katharina Finke,

Sebastian Matenaer, Ina Meier, and Benedikt Zinn

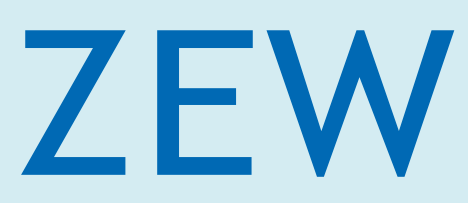

Zentrum für Europäische Wirtschaftsforschung $\mathrm{GmbH}$

Centre for European

Economic Research 
Discussion Paper No. 14-047

\title{
Evidence on Book-tax Differences and Disclosure Quality Based on the Notes to the Financial Statements
}

\author{
Maria Theresia Evers, Katharina Finke, \\ Sebastian Matenaer, Ina Meier, and Benedikt Zinn
}

Download this ZEW Discussion Paper from our ftp server:

http://ftp.zew.de/pub/zew-docs/dp/dp14047.pdf

Die Discussion Papers dienen einer möglichst schnellen Verbreitung von neueren Forschungsarbeiten des ZEW. Die Beiträge liegen in alleiniger Verantwortung der Autoren und stellen nicht notwendigerweise die Meinung des ZEW dar.

Discussion Papers are intended to make results of ZEW research promptly available to other economists in order to encourage discussion and suggestions for revisions. The authors are solely responsible for the contents which do not necessarily represent the opinion of the ZEW. 


\title{
Evidence on Book-tax Differences and Disclosure Quality Based on the Notes to the Financial Statements
}

\author{
Maria Theresia Evers*, Katharina Finke*, Sebastian Matenaer**, \\ Ina Meier**, Benedikt Zinn*
}

July 2014

\begin{abstract}
The German Accounting Law Modernization Act (BilMoG) represents a change in paradigm with regard to the traditionally close relationship between financial and tax accounting in Germany. At the same time, requirements on the disclosure of deferred taxes were revised considerably. We make use of these new disclosure provisions to disaggregate firms' deferred tax position and to analyze the components of temporary book-tax differences that add to the reporting gap in Germany. To this end, we apply a unique dataset of hand-collected information from individual financial statements for the fiscal year 2010. We find considerable differences between financial and tax accounting and observe that temporary book-tax differences are mainly associated with mandatory differences in accounting for provisions. The scope and quality of tax-related disclosures vary substantially and the overall disclosure quality is low. In order to identify the determinants of the heterogeneity of disclosure quality, we construct an index for voluntary and mandatory disclosure of deferred tax information and conduct multivariate analyses to explain firms' disclosure decisions. We show that the recognition of deferred tax assets and liabilities on the face of the balance-sheet is significantly and positively related with disclosure quality in the notes to the financial statements. Further, our results suggest that larger firms are more likely to have highquality tax disclosures and that high implementation costs could also explain the observed shortfalls in disclosure quality. Moreover, we find that different reporting incentives might apply if reporting on losses is assessed in isolation. We use these insights to derive implications for the discussion about whether and how to reform disclosure requirements under German GAAP.
\end{abstract}

JEL Classification: H20, H25, K34, M41

Keywords: book-tax conformity; book-tax differences; deferred taxes; disclosure quality; tax reporting

\footnotetext{
* ZEW Mannheim

** $\quad$ University of Mannheim
}

We thank Ernst \&Young for their support within the framework of the cooperation on Tax Accounting. Furthermore, we thank the participants in the Doctoral Research Seminar 2014 at WU Vienna and the participants in the $4^{\text {th }}$ Workshop on Current Research in Taxation at University of Muenster for their helpful comments. 


\section{Introduction}

Enhanced transparency in firms' tax reporting has been called for by various parties in the last years. Most recently, the discussion on the profit shifting activities of multinational corporations (BEPS) has given rise to the claim that these MNEs should be obliged to disclose profits and tax payments on a per-country basis (so called countryby-country reporting) (Spengel et al. (2014)). Similarly, it has been the objective of the German Accounting Law Modernization Act (Bilanzrechtsmodernisierungsgesetz (BilMoG)) enacted in 2010 to enhance the information value and transparency of financial statements. Moreover, the BilMoG Act constitutes a change in paradigm with regard to the traditionally close relationship between financial and tax accounting. The abolishment of the reverse authoritative principle implies a transition from a so-called one-book system in Germany towards a more two-book oriented system with two independent sets of accounting rules. Interestingly, this development is contrary to the ongoing discussion in the US where arguments for a stronger alignment of the two sets of accounts are brought forward (Desai (2003; 2005); Hanlon/Heitzman (2010)). The analysis thus provides valuable insights into the general debate to what extent financial and tax accounting should be aligned.

As an additional element of the reform, accounting for deferred taxes and tax disclosure requirements under German GAAP were revised considerably. In particular, the introduction of the temporary approach applied in accounting for deferred taxes and the new disclosure rules of Sec. 285 No. 29 of the German Commercial Code (HGB) potentially provide new insights into the actual relationship between financial and tax accounting and therefore more transparency.

Accordingly, the objectives of this paper are to study firms' reporting behavior after the implementation of the BilMoG-Act and to make use of the additional disclosures on deferred taxes in order to identify book-tax differences from publicly available data. In this regard, we make two contributions. First, we assess whether the new rules of disclosure meet the objective of increased transparency on firms' tax positions, in particular whether they provide sufficient information to reliably determine firms' tax positions from financial statements. We use these insights to derive implications for the discussion about whether and how to reform disclosure requirements with regard to deferred taxes. Second, in view of the heterogeneity in disclosure behavior, we identify the relevant determinants of firms' disclosure quality in a multivariate regression analysis. In 
order to address these research questions, we apply a unique dataset of hand-collected information from individual financial statements for the fiscal year $2010 .^{1}$ This comprehensive dataset enables us to disaggregate firms' deferred tax position and to shed light on the components of temporary book-tax differences that add to the reporting gap in Germany.

To address the first research question, we disaggregate deferred taxes into categories in order to understand the sources and origins of the reporting gap. This approach is in line with recent U.S. research (e.g. Poterba et al. (2011) and Raedy et al. (2011)). To our knowledge, we provide the first detailed analysis of book-tax differences and the components of deferred taxes in Germany for a significant sample of individual financial statements. Previous German literature, in contrast, mainly uses information from consolidated financial statements (e.g. Kager et al. (2011)) which comes at the cost that no direct link can be established to tax accounting based on the separate entity approach. Our analysis reveals considerable differences between financial and tax accounting. Moreover, we find that temporary book-tax differences mainly result from mandatory differences in accounting for provisions. As several corporations exceed current disclosure requirements and provide additional quantitative information on deferred taxes, we are not only able to identify the sources of the German reporting gap, but also the amount of temporary book-tax differences and estimate future tax consequences for a considerable subsample of 158 corporations.

Given the substantial heterogeneity in disclosure quality, the second part of the analysis addresses the question of why some firms decide to disclose detailed information about expected future tax consequences, while others do not even comply with the regulations of Sec. 285 No. 29 HGB. In an attempt to provide explanations on the determinants of tax disclosure quality, we construct an index for voluntary and mandatory disclosure of deferred tax information and conduct multivariate analyses to explain firms' disclosure decisions. Overall, our results suggest that companies which disclose deferred taxes on their balance sheets as well as larger ones are more likely to have high-quality tax disclosures and that high implementation costs might also explain the observed shortfalls in disclosure quality. We also find that different reporting incentives may apply if reporting on losses is assessed in isolation. In fact, the existence of deferred taxes without

1 In this context, we build on earlier work by Zinn (2012), chapter 4.2 and Matenaer (2013), chapter 4.3. 
clear and transparent reporting guidelines creates information asymmetry about future tax consequences between the users of financial statements and the management and provides ample room for earnings management.

The paper proceeds as follows: Section 2 outlines the institutional background of the BilMoG-Act and the changed provisions with respect to accounting for deferred taxes. Section 3 gives an overview of the related international and national literature. Subsequently, we present the results of our descriptive and empirical analysis in Section 4. First, subchapter 4.1 describes the sample and our hand-collected dataset. Section 4.2 shows the results of analyzing the notes to the financial statements and provides evidence on the sources and magnitude of the reporting gap. In Section 4.3 we present the research design of our empirical analysis as well as the results of our attempt to identify determinants of disclosure quality. Finally, Section 5 concludes.

\section{Institutional background}

The German Accounting Law Modernization Act (BilMoG) entered into force in 2010. While its main intention was to increase the information value and transparency of financial statements by attaining convergence towards International Financial Reporting Standards (IFRS), the reform act has not only affected numerous aspects of financial reporting, but also changed the traditionally close relationship between financial and tax accounting in Germany. One of the main tax amendments brought by the BilMoG-Act is seen in the revision of Sec. 5 (1) 1 EStG and thereby the abolishment of the reverse authoritative principle (umgekehrte Maßgeblichkeit, Sec. 5 (1) 2 EStG (old version)) allowing tax accounting options to be exercised independently from the accounting treatment in individual financial statements. The advanced flexibility in both financial and tax accounting created by the BilMoG-Act is expected to increase book-tax differences in Germany (Herzig et al. (2011)), thus broadening the scope of deferred taxes.

In addition, accounting for deferred taxes under German GAAP was fully revised and more or less adopted to the concept of IAS 12 within the framework of the BilMoG Act. One of the most substantial changes in this regard is the switch to the internationally prevailing temporary differences approach. ${ }^{2}$ The principal aim of the newly implemented Sec. 274 HGB is to account for temporary differences between financial and tax ac-

2 The temporary differences approach considers temporary differences between the carrying amount of assets or liabilities and their tax bases. In other words, the focus of the deferred tax calculation in the temporary differences approach is on differences that appear on the balance-sheet. 
counting which dissolve over time. ${ }^{3}$ Deferred tax assets may also be recognized with regard to tax loss carry-forwards to the extent that the corporation expects sufficient taxable profits to utilize the carry forward within the next 5 years. Sec. 266 (2) and (3) HGB prescribe that deferred tax assets and liabilities should be presented as separate items in the balance sheet. According to Sec. 274 (1) HGB, corporations may choose between a balanced or a separate recognition of deferred tax assets and liabilities. Importantly, net deferred tax liabilities represent a future obligation and therefore have to be recognized and presented on the balance sheet, whereas the recognition and presentation of net deferred tax assets is optional. ${ }^{4}$ Hence, if deferred tax assets exceed deferred tax liabilities, corporations may either opt for a gross or a net presentation or they may choose not to present a net deferred tax asset at all. In other words, managers have a substantial deal of discretion when reporting on deferred taxes. As regards the valuation of deferred taxes, Sec. 274 (2) HGB stipulates that temporary book-tax differences and loss carry forwards should be measured with reference to the corporation's individual tax rate at the time at which the differences will reverse.

Sec. 285 Nr. $29 \mathrm{HGB}^{5}$ specifies further disclosure requirements with regard to the notes to the financial statement. Accordingly, all temporary book-tax differences and loss carry forwards on which the deferred taxes are based, i.e. the nature and source of deferred tax assets and liabilities, shall be disclosed in the notes. This not only applies to recognized deferred taxes, but also to those (net) deferred tax assets which the corporation has chosen not to present on its balance sheet. Moreover, Sec. 285 Nr. 29 HGB requires the disclosure of the tax rate applied to determine deferred taxes. Apart from that, there are no further quantitative disclosure requirements, i.e. qualitative disclosures are sufficient and no separate disclosure of the amount of any deferred tax asset or liability or a quantitative reconciliation between the carrying amount in the financial statements and the tax base are necessary. Furthermore, Sec. 285 HGB doesn't contain any guidance on the level of detail required so that heterogeneous reporting behavior across firms may be expected.

3 A deferred tax asset is recognized if the corporation will pay less income taxes in the future. A deferred tax liability is recognized if the corporation will pay more taxes in the future due to a transaction that took place during the current period.

4 Thereby, deferred tax assets on temporary differences may only be recognized in compliance with the prudence principle, i.e. corporations shall only recognize deferred tax assets if it is probable that taxable income will be available to utilize the deductible temporary differences.

5 According to Sec. 267 HGB, 274 a Nr. 5 and 288 (2) the requirements laid down in Sec. 274 and 285 only apply to large and medium-sized corporations. 
Generally, Sec. 275 (2) No. 18 resp. 275 (3) No. 17 HGB prescribes that the total income tax expense shall comprise the current income tax expense as well as the deferred tax expense or benefit and be disclosed on the face of the income statement. According to Sec. 274 (2) S. 3 HGB, the deferred tax expense or benefit, measured as the current year change in deferred tax assets and liabilities, shall be disclosed separately. This can be either done in the form of a sub-heading, a column entry or a "of which" note to the total income tax expense.

\section{Related literature}

Our paper relates to four different strands of literature. The first strand concerns the general discussion on book-tax conformity, i.e. the extent to which financial and tax accounting should be aligned. ${ }^{6}$ In short, while proponents such as Desai $(2003,2005)$ in particular point to a lower incentive for upward earnings management as well as downward tax planning if the two sets of accounts are aligned, opponents (e.g. Hanlon/Maydew (2009); Hanlon/Shevlin (2005)) argue that such conformity would decrease the informational value and transparency of accounting numbers. We contribute to this literature by examining whether the objective of increased transparency due to the convergence towards a more two-book oriented reporting system is actually met.

Secondly, since tax return data is usually not publicly available, there are numerous empirical studies, which aim at drawing conclusions on tax positions from information in the financial statements. Manzon/Plesko (2002) for instance measure the estimated taxable income as reported current tax expense divided by the corporate tax rate. As Hanlon (2003) points out, these approximation methods are, however, subject to several measurement problems and thus only deliver a rough estimate of the actual tax liability. Many academics therefore call for mandatory disclosure of additional tax information to refine the common estimation approaches (e.g. Tran (2010); Plesko (2006); McGill/Outslay (2004); Hanlon (2003)). Nevertheless, several studies tried to overcome the constraints of these standard approaches. On the one hand, there are some investigations that exceptionally had access to tax return data (e.g. Zinn/Spengel (2012); Lisowsky (2009); Plesko (2007); Plesko (2003); Mills et al. (2002)). On the other hand, several studies rely on enriched datasets including hand-collected detailed tax information from the notes to the financial statements which are usually not available in the

\footnotetext{
6 For an extensive overview see Hanlon/Heitzman (2010).
} 
standard databases. In this regard, Blaylock et al. (2012, p. 119) point out the potential of studies "that examine the details of firms' tax footnotes [...] to make an important contribution to our understanding of the link between large BTDs and earnings persistence”. Philips et al. (2004) use hand-collected information from firm’s financial statement disclosures and separate deferred tax assets and liabilities into eight different components, e.g. depreciation of tangible assets and tax carryforwards, to detect earnings management. Guenther (2011) and Raedy et al. (2011) examine the causes for the link between disaggregated book-tax differences as derived from the schedule of deferred taxes in the notes to the financial statements and earnings persistence. They find a positive relation between persistence and temporary book-tax differences. Poterba et al. (2011) identify the most important sources of (temporary) book-tax differences by decomposing deferred tax positions to explore corporations' support of tax reforms. Finally, Kager et al. (2011) use information on deferred taxes to approximate differences between German tax values and IFRS consolidated financial statements. The latter disaggregate deferred tax assets and liabilities for 18 German corporations into balancesheet items and conclude that the most important differences between IFRS consolidated accounts and tax accounts occur for intangible assets and provisions. ${ }^{7}$ To contribute to this strand of literature, we assess whether the new disclosure requirements on deferred taxes provide sufficient information on book-tax differences and enable the reliable determination of firms’ tax positions from financial statements.

Thirdly, only a small number of papers assesses the reporting behavior of German corporations after the BilMoG-Act. Froschhammer/Haller (2012) for instance examine 362 financial statements of German corporations with regard to the question whether accounting options are exercised in accordance with IFRS after the BilMoG-Act. They find that this is not the case for the majority of options. In their assessment of IFRS consolidated financial statements of the years 2009 and 2010, Keitz et al. (2011) conclude that the information quality of the notes to the financial statements is very heterogeneous. Likewise, Phillips (2011) includes 53 early adopters of the BilMoG-Act in his study and finds that for a significant part of the sample, mandatory information in the notes is not sufficient or even missing. Hahn et al. (2012) examine 132 consolidated financial statements of non-capital market oriented corporations prepared under German GAAP with regard to the implementation of the new regulations introduced by the Bil-

\footnotetext{
7 It should be noted that the study by Kager et al. (2011) also includes data of 18 Austrian corporations.
} 
MoG-Act. They conclude that the reporting quality depends in particular on the size of the corporation. To our knowledge, there has so far not been a comprehensive study on the reporting behavior of German corporations in individual financial statements after the revision of reporting on deferred taxes. First, our contribution therefore lies in the analysis of the latter. Moreover, we use these findings to derive implications for the discussion about whether and how to reform disclosure requirements with regard to deferred taxes, an insight also relevant for other countries and standard setters.

Finally, the fourth relevant strand of literature refers to the second part of our paper, namely the identification of determinants driving disclosure quality. In that regard, Healy/Palepu (2001) extensively review the empirical disclosure literature. Similarly, Ahmed/Courtis (1999) provide a comprehensive meta-study on this subject. ${ }^{8}$ Some papers explicitly assessed the relationship between disclosure behavior and measures of corporate governance (e.g. Ho/Wong (2001) and Eng/Mak (2003)). Most recently, Robinson/Schmidt (2013) analyzed firms' reporting quality with regard to the implementation of FIN 48. The major variables identified as determinants for disclosure quality in these studies will be discussed and explained in detail in Section 4.3. We contribute to the literature on disclosure quality by particularly exploring what factors drive the reporting quality of corporations with regard to deferred taxes.

\section{Empirical evidence}

\subsection{Sample and data collection}

We construct a hand-collected dataset of individual financial statements which contain the key information required in our approach, i.e. component-based information on deferred taxes. The benefit of this unique dataset is that tax related information disclosed in the notes to the financial statements can be exploited which is usually not covered in commercial datasets. For this purpose, we collect data from individual financial statements and construct our sample with virtually all listed German corporations for the fiscal year 2010. Most individual financial statements were taken from the German Federal Gazette (elektronischer Bundesanzeiger). ${ }^{9}$ If any financial statements were not available, the information was downloaded from the corporations' websites. In a second step, all tax-related data from the balance sheet, the income statement and the notes to the financial statement were collected and matched. Overall, for each corporation in our

For a broad overview, please also refer to Chavent et al. (2006) and Hassan/Marston (2010).

The electronic German Federal Gazette is available online, see https://www.bundesanzeiger.de. 
sample, more than 100 items were taken from the individual financial statements. ${ }^{10}$ The initial sample comprises 940 listed corporations. Of these, 65 firms were dropped because they are either affected by insolvency proceedings, liquidation or reorganization. Also, a total of 34 corporations from the financial industry were excluded due to systematic differences in their regulatory environment. Additionally, 39 corporations with incomplete or deviating financial years and 23 entities of a tax group were excluded. 91 observations were lost because we were not able to access those firms' individual financial statements or other information required when running our analyses. Finally, we exclude 223 small and medium-sized corporations, as several details in the notes to the financial statements are not required for those firms. ${ }^{11}$ Hence, the final sample comprises 465 corporations.

\subsection{Inferring BTD from the notes to the financial statements}

\subsubsection{Sample characteristics}

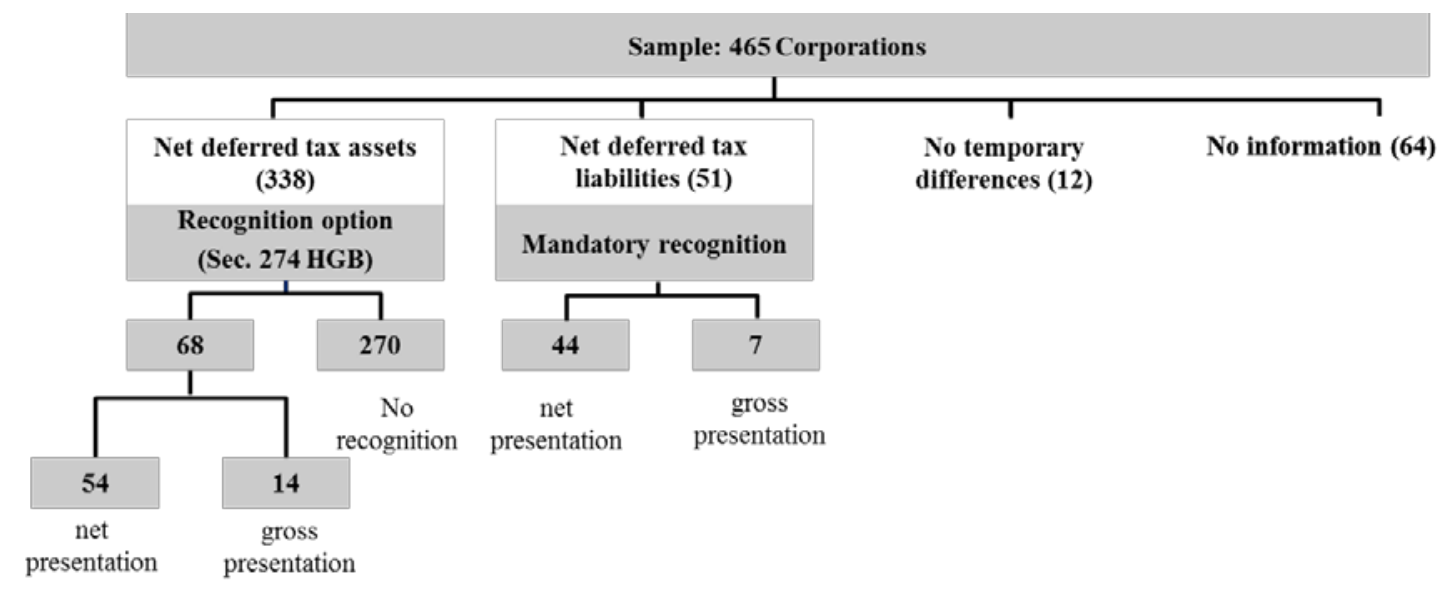

Figure 1: Sample characteristics: Recognition of deferred taxes in balance sheets

In Figure 1 we characterize the sample with respect to the disclosure of deferred tax assets and liabilities in the balance-sheet. We find that deferred tax assets and liabilities are rarely disclosed on the face of the balance-sheet in individual financial statements. Precisely, $346(=270+12+64)$ firms $(74.41 \%)$ do not recognize deferred tax assets and liabilities. Among these firms, 270 corporations make use of the accounting option of Sec. 274 HGB and report that they do not recognize net deferred tax assets, while 64 corporations - even though reviewed by external auditors - do not provide any information at all on deferred taxes. By contrast, 12 corporations explicitly state that tempo-

10 To further supplement the hand-collected data, we match each observation with information in the $D A F N E$ database provided by Bureau van Dijk, using both the German securities identification code (WKN) and the Crefo-ID, and validate the match using firm names and total assets.

11 For the classification criteria, see Sec. 267 HGB. 
rary differences between financial and tax accounting do not exist, i.e. they are assumed to prepare only one set of accounts for both financial and tax accounting (Einheitsbilanz). With respect to corporations recognizing deferred taxes on the face of the balance-sheet, 21 firms separately disclose gross amounts, while 98 corporations either report net deferred tax assets (54) or net deferred tax liabilities (44). Although not required on a mandatory basis, an overall of 68 corporations voluntarily recognize and disclose deferred tax assets and the corresponding tax benefit in their individual financial accounts.

The complexity and great deal of managers' discretion in accounting for deferred tax assets, in particular resulting from the recognition option, and the fact that deferred tax assets and deferred tax liabilities have opposing impact on profits after taxes plausibly suggests that it is used for earnings management. This conjecture is in line with empirical evidence that firms manage tax accounts to achieve financial targets or meet analysts' forecasts (e.g. Dhaliwal et al. (2004); Phillips et al. (2004)). In other words, the deferred tax account could provide a favorable and almost costless opportunity for earnings management, if managers have an incentive to achieve a particular financial target, e.g. avoid declines in profit after taxes, or threshold. In fact, neither dividend distributions (Ausschüttungssperre, (Sec. 268 (8) HGB)) ${ }^{12}$ nor actual tax payments are affected by the recognition of deferred tax assets. Moreover, as disclosure requirements and their enforcement are limited under German GAAP, reporting costs are low. Accordingly, accounting for deferred taxes provides managers with broad opportunities in their reporting decisions, leaving capital market participants and other stakeholders with considerable difficulties in inferring book-tax differences and firms' future tax positions. Moreover, the discretion in accounting for deferred taxes creates information asymmetry between the users of financial statements and the management and, thus, contradicts the main intention of the BilMoG-Act to increase the information content of financial statements prepared under German GAAP. To sum up, deferred taxes are a highly relevant account to study firms’ reporting behavior.

12 Pursuant to Sec. 268 (8) HGB tax benefits resulting from the recognition of deferred tax assets must not be distributed. 


\subsubsection{Estimating current and future tax consequences}

As deferred taxes potentially affect profits after taxes, ${ }^{13}$ we assess the materiality of deferred taxes in relation to profits before taxes. In that respect, in the first row of Table 1, we report that deferred tax expenses and benefits may play an important role in firms' profits. For instance, for $10 \%$ of the firms in the subsample, deferred tax expenses amount to almost $60 \%$ of profit before taxes. Relating deferred tax assets and liabilities to current year's profits before taxes informs about the magnitude of future tax consequences resulting from firms' temporary book tax differences; an information particularly useful for external users of financial statements demanding information on firms' future economic prospects. As displayed in the second row of Table 1, deferred taxes can be material in terms of their potential effects on future profits and cash-flows. The mean estimated future tax consequence amounts to $19.17 \%$. In other words, the immediate reversal of all temporary book-tax differences would come, on average, along with a tax benefit of approximately one fifth of the current year's profit before taxes. This is substantial.

Table 1: Estimation of future tax consequences due to deferred taxes

\begin{tabular}{|l|l|l|lll|}
\hline Estimated future tax consequences & Mean & $\begin{array}{l}\text { Standard } \\
\text { Deviation }\end{array}$ & $\mathbf{5 0 \%}$ & $\mathbf{7 5 \%}$ & $\mathbf{9 0 \%}$ \\
\hline \hline $\begin{array}{l}\text { Ratio of deferred taxes (deferred tax } \\
\text { expense) to profit before taxes }\end{array}$ & $27.94 \%$ & 0.7748 & $5.53 \%$ & $24.01 \%$ & $57.99 \%$ \\
\hline $\begin{array}{l}\text { Estimated future tax consequence, } \\
\text { total [(deferred tax assets-deferred } \\
\text { tax liabilities) / profit before taxes] }\end{array}$ & $19.17 \%$ & 1.2184 & $0.00 \%$ & $3.41 \%$ & $48.51 \%$ \\
\hline $\begin{array}{l}\text { Estimated future tax consequence, } \\
\text { unused tax loss-carryforward }\end{array}$ & $63.61 \%$ & 1.5532 & $0.00 \%$ & $52.50 \%$ & $195.75 \%$ \\
\hline
\end{tabular}

Note: All differences are winsorized at the first and $99^{\text {th }}$ percentile. Observations: 158 corporations.

Likewise, the potential income effects of recoverable tax loss-carryforwards are considerably high. For firms reporting deferred tax assets on unused tax loss-carryforwards, the average expected tax benefit amounts to 63.61\%. For one tenth of the corporations in the subsample, future tax benefits resulting from the use of recoverable tax losscarryforwards exceed roughly $200 \%$ of current year's profit before taxes. This finding is

13 A deferred tax benefit increases profits after taxes, the opposite applies for deferred tax expenses. 
generally in line with evidence on the substantial amount of firm-specific tax losscarryforwards in Germany (Dwenger/Walch (2011)).

\subsubsection{Decomposing deferred tax assets and liabilities}

We extend the analysis by having a closer look on what information is disclosed in the notes to the financial statements. This allows us to address the question whether this information is useful to identify the sources of firms' book-tax differences. To this end, we take advantage of the new rules of disclosure under Sec. 285 No. 29 HGB and disaggregate total deferred taxes into its components. Overall, we form twelve distinct categories of temporary differences between financial and tax accounting. These categories capture differences between the carrying amounts of assets and liabilities and the corresponding tax bases as well as firms' recoverable loss-carryforwards. 
Table 2: Components of deferred tax assets and liabilities (qualitative)

\begin{tabular}{|c|c|c|c|c|}
\hline \multirow{2}{*}{ Categories } & \multicolumn{4}{|c|}{ \# firms } \\
\hline & Total & $\begin{array}{c}\text { Deferred tax } \\
\text { asset }\end{array}$ & $\begin{array}{c}\text { Deferred tax } \\
\text { liability }\end{array}$ & $\begin{array}{c}\text { Both / } \\
\text { undefined }\end{array}$ \\
\hline \multicolumn{5}{|l|}{ Assets } \\
\hline Intangible assets & 15 & 8 & 7 & --- \\
\hline Capitalized R\&D expenses & 4 & -- & 4 & -- \\
\hline Goodwill & 11 & 8 & 3 & -- \\
\hline Tangible assets & 105 & 52 & 39 & 14 \\
\hline Financial assets & 46 & 20 & 22 & 4 \\
\hline Shareholdings & 41 & 16 & 21 & 4 \\
\hline Loans & 6 & 5 & 1 & 0 \\
\hline Inventories & 28 & 25 & 3 & 0 \\
\hline Receivables and other assets & 56 & 24 & 24 & 8 \\
\hline \multicolumn{5}{|l|}{$\begin{array}{l}\text { Liabilities } \\
\end{array}$} \\
\hline "Tax free reserves (Sec. 6b EStG) & 14 & 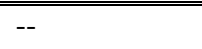 & 14 & $\begin{array}{l}-- \\
\end{array}$ \\
\hline Provisions & 266 & 220 & 21 & 25 \\
\hline Pension provisions & 164 & 147 & 13 & 4 \\
\hline Other provisions & 203 & 173 & 8 & 22 \\
\hline Accounts payable & 29 & 13 & 12 & 4 \\
\hline \multicolumn{5}{|l|}{ Group category (others) } \\
\hline " Other temporary differences & 84 & 29 & 38 & 17 \\
\hline \multicolumn{5}{|l|}{ Losses } \\
\hline "Recoverable tax loss-carryforward & 166 & 166 & $\begin{array}{l}-- \\
\end{array}$ & "-- \\
\hline
\end{tabular}

Note: Observations: 318 corporations. Please also note that for aggregate positions (Financial assets, Provisions) the figures do not necessarily add up from the sub-categories, but they account for those companies that provide information on both subcategories.

Table 2 provides an overview of how frequently each of the 13 categories of temporary differences is reported in the sample. Most remarkably, only 318 of the 465 corporations in the sample (68.39\%) fulfill their disclosure obligations (by Sec. 285 No. 29 HGB) and provide information on the sources of book-tax differences. Besides the 64 corporations providing no information at all about deferred taxes, 83 corporations do neither provide qualitative nor quantitative information on temporary differences or on tax loss-carryforwards which the (un-)recognized deferred tax assets and liabilities are based on.

For the subsample of 318 disclosing corporations, the most frequently disclosed category is provisions. The latter includes pension provisions as well as all other provisions, e.g. provisions for contingent losses. Approximately $84 \%$ of corporations in the sub- 
sample (266) report differences between the carrying amount of provisions and their tax bases. This is not surprising, since regulations governing accounting for provisions differ considerably between the commercial and the tax code. Due to the stricter recognition and measurement criteria for tax accounting purposes, the number of firms reporting deferred tax assets (220) on provisions exceeds the number of firms disclosing deferred tax liabilities by far (21). ${ }^{14}$ The most important source of deferred tax liabilities is tangible assets, which can mainly be attributed to the application of tax-favorable depreciation schemes. As mentioned above, such accounting options may be exercised independently from the treatment under financial accounting since the implementation of the BilMoG-Act in 2010. Concerning deferred tax assets on loss-carryforwards, 166 corporations expect future taxable benefits resulting from unused and recoverable losscarryforwards. In this regard, it is also important to note that 100 corporations either report that unused tax loss-carryforwards do not exist or that existing tax losscarryforwards are not recoverable, i.e. there is a probability that there will be no taxable profits available within the next five years against which the carryforward can be setoff.

As described in section 2, the new rules of disclosure of Sec. 285 No. 29 HGB do not stipulate quantitative disclosures on temporary book-tax differences in the notes to the financial statement. However, a subsample of 158 corporations voluntarily provides such quantitative information on the different components of deferred tax assets and liabilities. For these corporations, temporary book-tax differences can be computed by grossing-up of deferred tax assets and liabilities with the firm-specific tax rate identified from the notes. ${ }^{15}$

Table 3 offers insights into the amount of temporary book-tax differences for the subsample of 158 corporations. Overall, the means of temporary differences vary widely across the thirteen categories of deferred tax assets and liabilities. Notably, temporary deductible differences exceed temporary taxable differences for all categories, except for shareholdings. In line with Table 2, provisions are not only the most mentioned source of book-tax differences, but also account for the highest amount of temporary differences in our sample. In particular, the carrying amounts of other provisions differ

14 For 25 corporations reporting on deferred taxes on provisions we cannot identify whether a net deferred tax asset or a net deferred tax liability exists (see Table 2).

15 The mean tax rate for 331 corporations (134 corporations do not disclose tax rates at which deferred taxes are measured, despite being required by accounting standards) is $29.16 \%$. 
remarkably from the tax bases (EUR 85,281,430 and EUR 1,101,826 respectively). The same holds true for tangible assets and inventories.

Table 3: Components of temporary differences (quantitative)

\begin{tabular}{|c|c|c|c|c|c|c|}
\hline \multirow{2}{*}{ Category } & \multirow{2}{*}{ \# firms } & \multicolumn{2}{|c|}{$\begin{array}{l}\text { Temporary } \\
\text { deductible differences }\end{array}$} & \multirow{2}{*}{ \# firms } & \multicolumn{2}{|c|}{$\begin{array}{l}\text { Temporary } \\
\text { taxable differences }\end{array}$} \\
\hline & & Mean & $\begin{array}{l}\text { Standard } \\
\text { Deviation }\end{array}$ & & Mean & $\begin{array}{l}\text { Standard } \\
\text { Deviation }\end{array}$ \\
\hline \multicolumn{7}{|l|}{ Assets } \\
\hline \multicolumn{7}{|l|}{ Intangible assets } \\
\hline Capitalized R\&D expenses & -- & -- & -- & 2 & $5,200,058$ & $6,934,442$ \\
\hline Goodwill & 4 & $4,588,891$ & $6,152,945$ & 1 & $3,343,333$ & -- \\
\hline Tangible assets & 39 & $51,936,120$ & $269,183,600$ & 23 & $36,902,790$ & $85,573,850$ \\
\hline \multicolumn{7}{|l|}{ Financial assets } \\
\hline Shareholdings & 11 & 557,560 & 572,613 & 13 & $25,864,260$ & $70,792,740$ \\
\hline Loans & 3 & $1,885,890$ & $1,759,153$ & 1 & 96,552 & -- \\
\hline Inventories & 15 & $66,080,170$ & $235,411,900$ & 3 & $62,391,724$ & $107,227,859$ \\
\hline Receivables and other assets & 20 & $1,551,537$ & $2,831,574$ & 17 & $1,317,822$ & $2,594,228$ \\
\hline \multicolumn{7}{|l|}{ Liabilities } \\
\hline \multicolumn{7}{|l|}{ Tax free reserves } \\
\hline (Sec. 6b EStG) & -- & -- & -- & 3 & $1,827,765$ & 245,093 \\
\hline \multicolumn{7}{|l|}{ Provisions } \\
\hline Pension provisions & 62 & $20,040,470$ & $85,199,680$ & 12 & $3,404,747$ & $7,568,550$ \\
\hline Other provisions & 89 & $85,281,430$ & $663,236,400$ & 14 & $1,101,826$ & $2,582,853$ \\
\hline Accounts payable & 11 & $18,241,490$ & $43,639,820$ & 7 & 905,318 & 811,267 \\
\hline \multicolumn{7}{|l|}{ Group category (others) } \\
\hline Other temporary differences & 31 & $9,244,340$ & $17,463,770$ & 28 & $7,100,666$ & $15,781,870$ \\
\hline \multicolumn{7}{|l|}{ Losses } \\
\hline "Unused tax loss-carry forward & 73 & $41,140,810$ & $125,205,900$ & 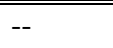 & 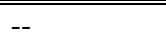 & 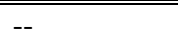 \\
\hline
\end{tabular}

Note: Observations: 158 corporations.

As regards firms' deferred tax assets on tax loss-carryforwards, the last row of Table 3 also shows that 73 corporations provide quantitative information on unused tax losscarryforwards, which average EUR 41,140,810. In this regard, it is important to note that only recoverable losses, i.e. tax loss-carryforwards for which firms expect that they can be utilized within the next five years, can give rise to deferred tax assets. However, as several firms exceed reporting requirements it is possible to analyze the recoverability and the expected economic consequences of loss-carryforwards in future periods as well as firms' expected economic prospects based on a limited number of firms. 


\section{Interim Conclusion}

Our descriptive results indicate that Germany is far away from a one-book accounting system. Quite the opposite, firm-specific temporary book-tax differences can be large and material in terms of their potential effect on future profits and cash-flows. Our findings suggest that accounting for provisions (mostly mandatory book-tax differences) as well as unused tax loss-carryforwards are at the heart of book-tax differences in Germany. The two key lessons learnt from the examination of firms' notes to the financial statements are the following: First, taking into account the considerable impact of deferred taxes on firms' future economic prospects, the lack of objective and specific accounting regulations for deferred taxes under current German GAAP must be criticized. That is, both the discretion in recognizing net deferred tax assets and the unspecific disclosure requirements of Sec. 285 No. 29 HGB without mandatory quantifications create information asymmetry between the management and the users of financial statements and contradict the objective of the BilMoG-Act to increase the information content and transparency of financial statements in Germany. ${ }^{16}$ Hence, the possibility of inferring taxable income from financial statements remains limited. Therefore, we recommend abolishing the recognition option for deferred tax assets to reduce managerial discretion. Furthermore, disclosure requirements for deferred taxes in the notes should become more detailed and precise as well as include mandatory quantifications. These findings could also be of relevance for standard setters outside of Germany. Second, firms exhibit substantial heterogeneity in their reporting behavior concerning deferred taxes. Consistent with the above criticism, actual tax disclosures are inconsistent in terms of the level and quality of information provided across firms. While some corporations report comprehensively on the sources and magnitude of book-tax differences, others disclose no information at all.

16 Similar, Küting/Seel (2009, p. 925). 


\subsection{Determinants of disclosure quality}

On the basis of this insight, we now address the question why some firms disclose detailed information on deferred taxes and future tax consequences, while others do not even comply with the disclosure requirements of Sec. 285 No. 29 HGB. In doing so, our research design focuses on the factors that influence the disclosure of information on deferred taxes, rather than their existence. In particular, we aim at understanding the observed heterogeneity in firms' reporting behavior and at identifying determinants of tax disclosure policy.

\subsubsection{Research Design}

\section{Disclosure index}

The quality of tax-related disclosures is measured by applying a simple disclosure model that consists of two components. ${ }^{17}$ The first component measures disclosure compliance, i.e. the compliance with the mandatory disclosure requirements of Sec. $274 \mathrm{HGB}$, Sec. 284 (2) No. 1 HGB and Sec. 285 No. 29 HGB, which consists of five mandatory disclosure items (Table 4). The second component measures voluntary disclosures. In fact, many firms exceed the disclosure requirements foreseen by German GAAP and provide external users of financial statements with clarifying information on deferred taxes. The selection of voluntary disclosure items is not only based on the recommendations of DRS $18^{18}$ and previous literature on deferred tax disclosures (e.g. Prystawik/Schauf (2011) and Oser et al. (2011)), but we also consider the disclosures encountered in the course of the review of individual financial statements as discussed above. Overall, seven items of voluntary disclosure were identified. Accordingly, the aggregate disclosure score, which is the sum of mandatory and voluntary disclosure items, has a maximum value of 12 (Table 4).

17 For a similar procedure, see Robinson/Schmidt (2013).

18 Deutscher Rechnungslegungsstandard (German Accounting Standard) 18. 


\begin{tabular}{|c|c|c|c|c|c|c|}
\hline \multicolumn{2}{|c|}{ Item } & \# & Mean & $\begin{array}{l}\text { Standard } \\
\text { Deviation }\end{array}$ & Min & Max \\
\hline \multicolumn{7}{|c|}{ Mandatory disclosure of/that... (Sec. 274 HGB; Sec. 284 (2) No. 1 HGB; Sec. 285 No. 29 HGB) } \\
\hline (1) & $\begin{array}{l}\text { deferred taxes on the face of the balance-sheet and } \\
\text { corresponding explanations in the notes } \\
\text { or } \\
\text { the corporation does not recognize net deferred tax } \\
\text { assets }\end{array}$ & 465 & 0.8451 & 0.3621 & 0 & 1 \\
\hline$(2)$ & $\begin{array}{l}\text { the tax rates at which deferred taxes have been meas- } \\
\text { ured }\end{array}$ & 465 & 0.7134 & 0.4527 & 0 & 1 \\
\hline (3) & $\begin{array}{l}\text { temporary differences on which (un-) recognized } \\
\text { deferred taxes are based on (qualitative) }\end{array}$ & 465 & 0.6839 & 0.4655 & 0 & 1 \\
\hline (4) & $\begin{array}{l}\text { tax loss-carryforwards have been taken into consider- } \\
\text { ation when reporting on deferred taxes (qualitative) }\end{array}$ & 465 & 0.5677 & 0.4959 & 0 & 1 \\
\hline (5) & $\begin{array}{l}\text { deferred tax expenses or benefits on the face of the } \\
\text { income statement }\end{array}$ & 119 & 0.4538 & 0.4999 & 0 & 1 \\
\hline Manc & Hatory disclosure & 465 & 2.933 & 1.502 & 0 & 5 \\
\hline \multicolumn{7}{|c|}{ Voluntary disclosure of... } \\
\hline (6) & $\begin{array}{l}\text { aggregate deferred tax assets } \\
\text { (quantitative) }\end{array}$ & 369 & 0.404 & 0.4913 & 0 & 1 \\
\hline (7) & $\begin{array}{l}\text { temporary differences on which (un-) recognized } \\
\text { deferred taxes are based (quantitative) }\end{array}$ & 465 & 0.3054 & 0.4611 & 0 & 1 \\
\hline (8) & $\begin{array}{l}\text { recoverable loss-carryforwards } \\
\text { (quantitative) }\end{array}$ & 465 & 0.3376 & 0.4734 & 0 & 1 \\
\hline (9) & $\begin{array}{l}\text { non-recoverable loss-carryforwards } \\
\text { (quantitative) }\end{array}$ & 465 & 0.1255 & 0.3317 & 0 & 1 \\
\hline$(10)$ & $\begin{array}{l}\text { the different types of taxes that the loss-carryforward } \\
\text { is based on (quantitative) }\end{array}$ & 115 & 0.4869 & 0.5020 & 0 & 1 \\
\hline (11) & $\begin{array}{l}\text { temporary differences at the level of all entities of the } \\
\text { tax group are recognized in the controlling entity's } \\
\text { financial statement }\end{array}$ & 111 & 1 & 0 & 1 & 1 \\
\hline (12) & $\begin{array}{l}\text { the sources and magnitude of temporary differences } \\
\text { that occur at the levels of group entities (quantitative) }\end{array}$ & 10 & 1 & 0 & 1 & 1 \\
\hline \multicolumn{2}{|c|}{ Voluntary disclosure } & 465 & 1.469 & 1.641 & 0 & 7 \\
\hline \multicolumn{2}{|c|}{ Aggregate disclosure } & 465 & 4.402 & 2.793 & 0 & 12 \\
\hline
\end{tabular}

Table 4 provides descriptive statistics for the disclosure scores and the individual score items for the entire sample of 465 observations. The means of the respective reporting items indicate the degree to which corporations provide disclosures on the single com- 
ponents. For instance, the mean of 0.8451 for mandatory item 1 reflects strong compliance whereas the mean of 0.5677 (item 4) unfolds much weaker willingness to report on losses.

Like most other disclosure studies we apply an item-based approach using a dichotomous procedure (Chavent et al. (2006, p. 184)). ${ }^{19}$ In order to reduce subjectivity, the applied approach is unweighted, i.e. each disclosure item is assumed to be equally important (Ahmed/Courtis (1999, p. 36)). Put differently, all considered disclosure items score one if disclosed and zero if not. Moreover, following Cooke (1989, pp. 182-183), we explicitly account for the interrelationships between the different items and pay attention to the non-disclosure of items irrelevant to the firm. Accordingly, the score scheme is employed as follows:

$$
\text { Score }_{f}=\sum_{i=1}^{n} d_{f, i}
$$

with $\quad d_{f, i}=\left\{\begin{array}{l}1 \text { if item } \mathrm{d}_{\mathrm{i}} \text { is disclosed by the firm } \\ 0 \text { if item } \mathrm{d}_{\mathrm{i}} \text { is not disclosed by the firm } \\ \text { n.a. if item is not relevant to the firm }\end{array}\right.$

$n \quad=$ maximum number of items scored (here: 12 )

Once all items are scored, the disclosure index is calculated for each corporation. To this end, the index is computed as the number of items disclosed (score $f$ ) divided by the number of items expected to be disclosed $(m)$.

$$
\text { Disclosure index } x_{f}=\sum_{i=1}^{n} d_{f, i} / \sum_{i=1}^{m} d_{f, i}
$$

In other words, the disclosure index is a ratio of the actual score to the maximum score which a corporation is expected to achieve. Accordingly, corporations are not penalized for those disclosures that are not relevant to them. For example, only corporations that disclose a deferred tax asset or liability on the face of the balance-sheet are expected to

19 For a review of the previous disclosure studies, see e.g. Ahmed/Courtis (1999); Hassan/Marston (2010). 
report separately on deferred tax expenses or benefits on the face of the income statement.

Regression equation and hypotheses development

Our dependent variable is the disclosure index which is, by construction, a fraction and therefore constrained to be between zero and one. This specific structure of the dependent variable is accounted for in generalized linear model (GLM) estimators which are in this respect superior to OLS. ${ }^{20}$ Ordinary linear regression assumes that a constant change in explanatory variables results in a constant change in the dependent variable. This assumption, however, is no longer appropriate if the values of the dependent variable are bound between 0 and 1 . Therefore we chose a generalized linear model (GLM) which is shown to be adequate in situations where the dependent variable follows a distribution other than normal. In particular for this case, we take a GLM with a binomial distribution and a logit link function (Papke/Wooldridge (1996); Papke/Wooldridge (2008)). ${ }^{21}$ To empirically examine the specific determinants of disclosure quality, we estimate the following equation:

$$
\begin{aligned}
& \text { disclosure index }_{\mathrm{f}}=\alpha+\beta_{1} \text { recognition }_{\mathrm{f}}+\beta_{2} \text { ETR }+\beta_{3} \ln \left(\text { firmSize }_{\mathrm{f}}\right)+ \\
& \beta_{4} \text { liquidity }_{\mathrm{f}}+\beta_{5} \text { PTROA }_{\mathrm{f}}+\beta_{6} \text { leverage }_{\mathrm{f}}+ \\
& \beta_{7} \# \text { days }_{\mathrm{f}}+\beta_{8} \text { audit intensity }_{\mathrm{f}}+\beta_{9} \text { small - cap }_{\mathrm{f}}+ \\
& \beta_{10} \text { BIG }_{\mathrm{f}}+\beta_{11} \text { listing }_{\mathrm{f}}+\beta_{12} \text { shareholding }_{\mathrm{f}}+\beta_{13} \text { industry }_{\mathrm{f}}+\varepsilon_{\mathrm{f}}
\end{aligned}
$$

Accordingly, we model the quality of tax disclosures (disclosure index) as a function of variables which are expected to affect firms' disclosure decisions. Table 5 specifies the explanatory variables and summarizes our expectations on their relationship with disclosure quality.

First, we expect a positive link between the recognition of deferred taxes on the face of the balance sheet and the degree of detailed information provided in the notes to the financial statements. This may be seen as a rationale consequence of firms meeting the information requirements of investors. In this regard, Ahmed et al. (2006), for example, report that items recognized in financial statements are of higher relevance than those items that are merely disclosed in the notes. Accordingly, we expect the recognition of

20 To ensure comparability to previous studies, we nevertheless conduct a OLS regression as a robustness check in section 4.3.4.

21 We also include the robust option to obtain robust standard errors. 
deferred tax assets and liabilities to be positively correlated with disclosure quality and capture this effect with the binary variable recognition.

Second, when total tax expenses are equivalent to a high percentage of profit before taxes (effective tax rate), they become a major factor in firms' profit after taxes. Considering the materiality principle (Gleason/Mills (2002)), firms with high effective tax rates are therefore expected to provide additional information on their tax position to rationalize high tax payments. At the same time, low effective tax rates are widely associated with tax avoidance (Hanlon/Heitzman (2010, p. 139-141)). In line with political process theory (Giner Inchausti (1997, p. 54)), firms may thus be interested in disclosing more information on their tax position in order to justify low effective tax rates. Taken these two offsetting effects into account, the extent and quality of disclosure on deferred taxes is assumed to be related to firms' ratio of total tax expense to profits before taxes (ETR) to some extent, but we do not predict the direction of their relationship. 
Table 5: BilMoG and tax disclosure: Regression variables

\begin{tabular}{|c|c|c|}
\hline Variable & & Expectation \\
\hline \multicolumn{3}{|l|}{ Tax status } \\
\hline Recognition & $\begin{array}{l}\text { Dummy variable capturing if a corporation recognizes deferred taxes on the face } \\
\text { of the balance-sheet (1) or not ( } 0 \text { ) }\end{array}$ & + \\
\hline ETR & Ratio of total tax to annual profits before taxes (absolute) & 0 \\
\hline \multicolumn{3}{|c|}{ General disclosure variables } \\
\hline Firm size & Total assets reported on the balance-sheet (natural logarithm) & + \\
\hline Liquidity & Ratio of current assets to short-term accounts payable & - \\
\hline PTROA & Ratio of profits before taxes to total assets & 0 \\
\hline Leverage & Ratio of liabilities to total assets & + \\
\hline \multicolumn{3}{|c|}{ Implementation costs } \\
\hline Audit intensity & Audit-related fees paid divided by revenues. & + \\
\hline \# days & Number of days between closing date and the date of the audit opinion & - \\
\hline Small-cap & $\begin{array}{l}\text { Dummy variable capturing if the corporation is required to fulfill the disclosure } \\
\text { requirements of Sec. } 285 \text { No. } 29 \text { HGB only due to its listing in an EU-regulated } \\
\text { segment (1) or not (0) }\end{array}$ & - \\
\hline \multicolumn{3}{|c|}{ Firm monitoring } \\
\hline BIG4 & $\begin{array}{l}\text { Dummy variable capturing if the opinion was applied by one of the largest four } \\
\text { audit firms [Deloitte; Ernst \& Young; KPMG;PwC] (1) or not (0) }\end{array}$ & + \\
\hline Listing & $\begin{array}{l}\text { Dummy variable capturing if the corporation is listed in the market segment } \\
\text { Prime Standard (1) or not ( } 0 \text { ) }\end{array}$ & + \\
\hline Shareholding & $\begin{array}{l}\text { Dummy variable capturing if a known recorded shareholder has more than } 25 \% \\
\text { of direct or total ownership [BvD Independence Indicator: A] in the corporation } \\
\text { (1) or not (0) }\end{array}$ & - \\
\hline \multicolumn{3}{|c|}{ Other firm characteristics } \\
\hline Industry & NACE code & 0 \\
\hline
\end{tabular}

Note:,+ 0 and - denote the expected relationship between the dependent variable disclosure index and the independent variables as explained below.

Following previous disclosure literature (e.g. Lang/Lundholm (1993)), we also include four explanatory variables (firm size, liquidity, profitability and leverage) that have been identified to be correlated with the overall disclosure quality. First, we expect a positive relationship between firms' size, measured as the natural logarithm of total assets, and the level of tax-related disclosures. As reviewed in a meta-study by $A h$ med/Courtis (1999, pp. 44-49), there are several reasons for this link, e.g. economies of scale and higher visibility, complexity and demand for external funds of larger firms. However, the most important point in our setting is that costs associated with the adoption of new accounting and disclosure regulations are expected to be lower for large 
firms due to their more sophisticated internal reporting systems. It is therefore more likely that larger corporations may not only react to changes in accounting rules more quickly, but also provide higher levels of disclosure in the year of adopting new accounting standards (Murphy (1999)). In terms of firms’ liquidity, less liquid corporations are expected to disclose more information on deferred tax assets than others. As deferred tax assets represent future tax and cash-flow benefits, providing detailed information on those may support firms' credibility to meet short-term obligations. Moreover, as deferred tax assets may only be recognized if taxable profits are timely available to utilize the deductible temporary differences, ${ }^{22}$ reporting on deferred tax assets signals positive expectations on short-term future earnings. Accordingly, we expect the sign of the coefficient for liquidity, i.e. the ratio of current assets to short-term accounts payable, to be negative. By contrast, as disclosure of information is widely considered to be an instrument for reducing agency problems associated with costs of creditors (Robinson/Schmidt (2013, p. 15)), we control for firms' indebtedness and expect a positive relation between disclosure quality and leverage, i.e. the ratio of liabilities to total assets. Moreover, as previous research finds mixed evidence of firms' performance and disclosure quality, we include a measure of performance, i.e. the pretax return on asset (PTROA), but do not make predictions on the sign of the coefficient. ${ }^{23}$

The adoption of the temporary-differences approach under Sec. 275 HGB and the new disclosure requirements under Sec. 285 No. 29 HGB placed significant demand on firm and auditor resources (e.g. Maier/Weil (2009, p. 2735) and Küting/Seel (2009, p. 924)). To identify the extent to which such implementation and compliance costs explain the observed shortcomings in disclosure quality, we consider a number of variables that are assumed to proxy for implementation costs and efforts in reporting. We first expect a greater audit effort to be positively associated with the quality of disclosure of deferred taxes and use audit intensity, i.e. the amount paid for audit-related services during the fiscal year 2010 in relation to revenues, as a proxy. Moreover, we follow Robinson/Schmidt (2013, p. 13) and include the reporting lag, i.e. the number of days between the end of the fiscal year and the date of the audit opinion (\#days). Assuming that rather large firms have well-established tax and accounting departments and are therefore able to react immediately to changes in accounting regulations, we argue that \#days captures

22 For details, see Section 2.

23 For a review of the literature on the relationship between firms' profitability and disclosure quality, see Chavent et al. (2006, p. 189). 
the burden in terms of costs and efforts posed in particular on those (assumable smaller) corporations, which don't have such sophisticated systems and processes in place. Relatively higher implementation costs should in particular apply for corporations which are generally considered to be small, but are legally obligated to fulfill the disclosure requirements of large corporations due to their listing in an EU-regulated financial-market segment (Sec. 263 (3) 2 HGB). In this respect, we argue that, if after controlling for firm size, such firms are associated with lower disclosure quality, then we can assume that considerable implementation costs and the significant demand on firms' accounting department resources partially explain the observed shortcomings in disclosure quality. Accordingly, we include small-cap, i.e. a binary variable capturing if the corporation is required to disclose information on deferred taxes only because of its listing, and assume a negative relationship with disclosure quality.

In line with previous literature which suggests that external monitoring has an effect on disclosure quality (e.g. Robinson/Schmidt (2013)), we also consider the impact of the monitoring effort of different external users of financial statements on tax disclosure quality. Our prediction is that external monitoring efforts increase disclosure quality. We first include a variable that captures the impact of the outside auditor. Consistent with previous research (e.g. Rice/Weber (2011, p. 13) and Ettredge et al. (2011, p. 872)), we presume a higher disclosure quality when firms are audited by a Big4 company (BIG4). Second, it is expected that the level of transparency requirements in different financial-market segments influences firms’ disclosure quality. Accordingly, we predict that firms included in the Prime Standard of Deutsche Börse $A G^{24}$, i.e. the market segment with the highest transparency requirements in Germany, provide a higher level of disclosure quality than non-Prime Standard firms, i.e. we expect that listing, a binary variable, is positively associated with disclosure quality. Third, as agency theory suggests that monitoring efforts vary with shareholder population (Fan/Wong (2002, pp. 407-409)), we also control for ownership structure by adding shareholding to our estimation equation. This binary variable captures if a single shareholder has more than $25 \%$ of direct or total ownership in the corporation. In line with Cooke (1989, pp. 177178), information asymmetry is expected to be less prevalent in firms with majority

24 Deutsche Börse structures its markets on three levels of transparency (Prime, General and Entry Standard). Companies in the Prime Standard are, for example, required to prepare quarterly financial statements and maintain a corporate action timetable. For details, see http://deutsche-boerse.com. 
shareholders. Accordingly, we expect our measure of shareholder structure (shareholding) to be negatively associated with disclosure quality.

As several previous studies have found a relationship between the quality of disclosures and the industry sector (e.g. Cooke (1992)), while others report no differences in the disclosure level across industries (e.g. Watson et al. (2002)), we also include industry fixed effects. However, in line with Chavent et al. (2006, p. 190) we assume that there is no link between the disclosure of tax-related information and the different industry sectors.

\subsubsection{Descriptive Statistics}

To begin with, Table 6 provides descriptive statistics for the regression variables. Of special interest is the disclosure index, which averages 0.4946. As mentioned above, 64 corporations do not provide any information at all on deferred taxes and score zero, while 24 firms score one, i.e. they provide all mandatory and voluntary information which the firm is expected to disclose. Considering the mandatory disclosure index as used in one of the robustness tests discussed below, firms in our sample disclose, on average, 3.39 of the 5 mandatory disclosure items (67.94\%). Overall, 149 corporations provide all information required by German GAAP.

As already shown in Figure 1, a total of 119 (25.59\%) corporations in the sample recognize deferred tax assets and liabilities on the face of the balance-sheet. With respect to the ratio of total tax expenses to profit before taxes, corporations in our sample report, on average, an effective tax rate of $21.44 \% .^{25}$

Table 6 illustrates the heterogeneity in firm size and other explanatory variables across the sample.

25 Following Gupta/Newberry (1997, pp. 12-13) and Schmidt (2006, p. 598), the ETR is set to "1" when the ETR is greater than $100 \%$ and to " 0 " when the ETR is negative. Accordingly, the ratio of total taxes to profit before taxes ranges from zero, i.e. corporations report either negative or zero tax payments, to $100 \%$. 
Table 6: BilMoG and tax disclosure: Descriptive statistics

\begin{tabular}{|c|c|c|c|c|}
\hline Variable & Mean & $\begin{array}{l}\text { Standard } \\
\text { Deviation }\end{array}$ & Min & Max \\
\hline \multicolumn{5}{|c|}{ Dependent variable: disclosure index } \\
\hline Aggregate & 0.4946 & 0.2901 & 0 & 1 \\
\hline Mandatory & 0.6794 & 0.3359 & 0 & 1 \\
\hline \multicolumn{5}{|l|}{ Tax status } \\
\hline Recognition & 0.2559 & 0.4368 & 0 & 1 \\
\hline ETR & 0.2144 & 0.3048 & 0 & 1 \\
\hline \multicolumn{5}{|c|}{ General disclosure variables } \\
\hline Firm size (Total assets) & $1,879,154,000$ & $7,737,443,000$ & 690,892 & $59,950,000,000$ \\
\hline Liquidity & 19.8956 & 80.6478 & 0,05233 & 705.8519 \\
\hline PTROA & 0.02703 & 0.1711 & -0.9805 & 0.4478 \\
\hline Leverage & 0.3128 & 0.2275 & 0.0009 & 0.8951 \\
\hline \multicolumn{5}{|l|}{ Implementation costs } \\
\hline Audit intensity & 0.0763 & 0.2632 & 0.000012 & 2.1098 \\
\hline \# days & 80.4645 & 30.2094 & 27 & 217 \\
\hline Small-cap & 0.2624 & 0.4403 & 0 & 1 \\
\hline \multicolumn{5}{|l|}{ Firm monitoring } \\
\hline BIG4 & 0.6000 & 0.4904 & 0 & 1 \\
\hline Listing & 0.5333 & 0.4994 & 0 & 1 \\
\hline Shareholding & 0.6688 & 0.4711 & 0 & 1 \\
\hline
\end{tabular}

Note: All continuous explanatory variables are winsorized at the first and $99^{\text {th }}$ percentile.

Finally, the correlations ${ }^{26}$ among the twelve explanatory variables don't give any indication for an unacceptable level of multicollinearity in the data. ${ }^{27}$

\subsubsection{Empirical results}

Based on Equation (1), columns (1) - (3) of Table 7 present our main results for the final sample. Consistent with our expectations, we find a strong association between the recognition of deferred taxes and disclosure quality in Specification (1), but no significant relationship with firms' effective tax rate. The estimated coefficient of recognition is positive, indicating that the recognition of deferred taxes in the balance sheet yields enhanced disclosure quality in the notes to the financial statement. As already pointed out in the descriptive analysis, we accordingly argue that the abolishment of the recog-

26 See correlation matrix in the Annex (Table 8).

27 According to Farrar/Glauber (1967) harmful levels of multicollinearity are not present until bivariate correlations exceed 0.8 . 
nition option for net deferred tax assets under Sec. 274 HGB might not only avoid managers' discretion in accounting for deferred taxes, but also induce firms to disclose more precise information on deferred taxes and future tax consequences in the notes. Not surprisingly, we also find a significant and positive association between disclosure quality and firms' size. The results here, while generally consistent with the empirical disclosure literature, suggest higher knowledge and more efficient interactions between larger firms' accounting and tax department at the root of the relationship we observe. In line with our expectations, the significant negative coefficient of liquidity suggests that less liquid corporations tend to provide more detailed information on deferred taxes than others. By contrast, we cannot provide evidence for firms' profitability and leverage to be determinants of tax-related disclosure quality in all six model specifications. Similarly, we find no differences in disclosure level between industries.

After adding the measures of implementation costs in Specification (2), the results reported above remain largely unchanged. We cannot report significant results for audit intensity, i.e. the ratio of audit fees divided by revenues and \#days. We do find, however, a significant and negative relation between disclosure quality and small-cap. While this finding may indicate that high implementation and compliance costs explain the observed heterogeneity in tax-related disclosure policy, this is also consistent with the positive relationship between the level of disclosure and firms' size. That is, firms for which compliance and implementation costs are expected to be relatively low provide higher-quality tax disclosure as measured by our disclosure index. Put differently, high implementation costs make compliance with recently implemented accounting standards and high-quality disclosures less likely. While this holds particularly true for smaller firms, large corporations are expected to benefit from their specialized knowledge in tax and financial accounting and thus may react faster on changes in accounting and provide comprehensive disclosures in the year of adoption. 
Table 7: Regression results (GLM)

\begin{tabular}{|c|c|c|c|c|c|c|}
\hline \multirow[t]{2}{*}{ Disclosure index } & \multicolumn{4}{|c|}{ Main regressions } & \multicolumn{2}{|c|}{ Robustness test } \\
\hline & (1) & (2) & (3) & (4) & (5) & (6) \\
\hline \multicolumn{7}{|l|}{ Tax status } \\
\hline \multirow[t]{2}{*}{ Recognition } & $1.213^{* * *}$ & $1.176^{* * *}$ & $1.174 * * *$ & $1.310^{* * *}$ & & $0.882^{* * *}$ \\
\hline & $(0.106)$ & $(0.106)$ & $(0.107)$ & $(0.122)$ & & $(0.149)$ \\
\hline \multirow[t]{2}{*}{ ETR } & -0.0619 & -0.0853 & -0.0757 & -0.104 & -0.0982 & -0.232 \\
\hline & $(0.185)$ & $(0.182)$ & $(0.182)$ & $(0.192)$ & $(0.230)$ & $(0.242)$ \\
\hline \multicolumn{7}{|c|}{ General disclosure variables } \\
\hline \multirow[t]{2}{*}{ Firm size } & $0.128 * * *$ & $0.0778 * * *$ & $0.0956 * * *$ & $0.0920^{* *}$ & $0.0868 * *$ & $0.174 * * *$ \\
\hline & $(0.0259)$ & $(0.0259)$ & $(0.0341)$ & $(0.0358)$ & $(0.0398)$ & $(0.0483)$ \\
\hline \multirow[t]{2}{*}{ Liquidity } & $-0.00113^{* *}$ & $-0.00116^{* *}$ & $-0.00120 * *$ & -0.000982 & $-0.00131 *$ & $-0.00171^{* *}$ \\
\hline & $(0.000503)$ & $(0.000549)$ & $(0.000563)$ & $(0.000651)$ & $(0.000784)$ & $(0.000689)$ \\
\hline \multirow[t]{2}{*}{ PTROA } & 0.0870 & -0.146 & -0.209 & -0.316 & -0.136 & 0.223 \\
\hline & $(0.462)$ & $(0.473)$ & $(0.476)$ & $(0.490)$ & $(0.574)$ & $(0.538)$ \\
\hline \multirow[t]{2}{*}{ Leverage } & 0.251 & 0.273 & 0.238 & 0.126 & 0.195 & 0.397 \\
\hline & $(0.271)$ & $(0.270)$ & $(0.273)$ & $(0.289)$ & $(0.330)$ & $(0.354)$ \\
\hline \multicolumn{7}{|c|}{ Implementation costs } \\
\hline \multirow[t]{2}{*}{ Audit intensity } & & -0.0645 & -0.0808 & -0.181 & -0.173 & -0.131 \\
\hline & & $(0.176)$ & $(0.180)$ & $(0.216)$ & $(0.242)$ & $(0.281)$ \\
\hline \multirow[t]{2}{*}{ \# days } & & -0.00344 & -0.00379 & $-0.00490 *$ & -0.00457 & -0.00290 \\
\hline & & $(0.00236)$ & $(0.00239)$ & $(0.00267)$ & $(0.00291)$ & $(0.00332)$ \\
\hline \multirow[t]{2}{*}{ Small-cap } & & $-0.258^{*}$ & $-0.262 *$ & $-0.366 * *$ & $-0.354 * *$ & $-0.534 * * *$ \\
\hline & & $(0.139)$ & $(0.139)$ & $(0.151)$ & $(0.172)$ & $(0.169)$ \\
\hline
\end{tabular}




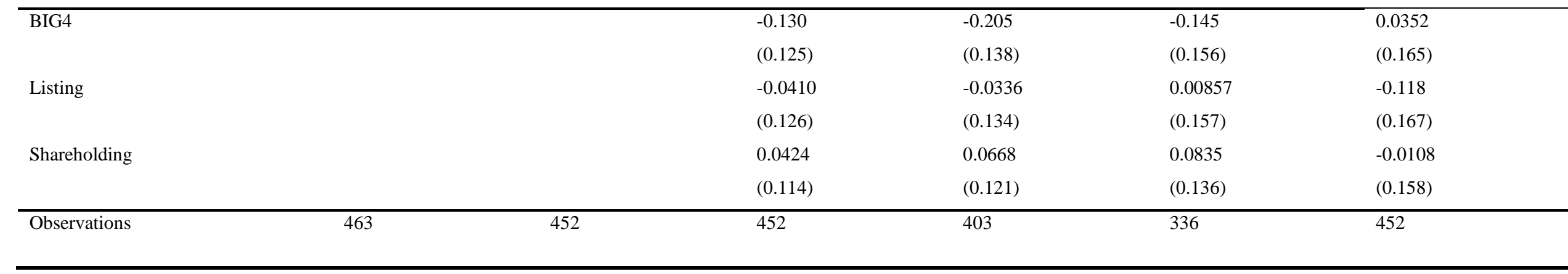

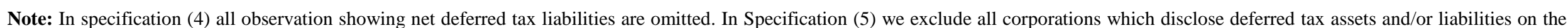

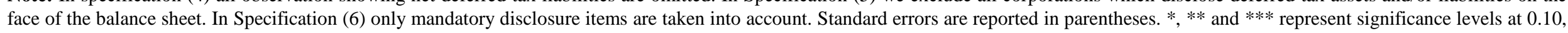
0.05 and 0.01 .

Please also note that this table only contains the regression coefficients; for marginal effects see Table 9 in the Annex. 
In order to determine whether disclosure quality may also be driven by the information requirements of external users of financial statements, we add three variables which approximate for external monitoring efforts in Specification (3). The signs and significance levels of the variables discussed above remain largely unchanged when the new variables are included. At the same time, we find no significant relationship between disclosure quality and external monitoring efforts. Although this result seems surprising at first glance, it is consistent with the findings of the comprehensive meta-study by Ahmed/Courtis (1999) reviewing the results of 29 studies on the association between corporate characteristics and disclosure quality. While reporting that the degree of compliance with mandatory disclosure requirements is significantly higher for corporations which are audited by larger audit firms, they find that a significant relationship cannot be identified if disclosure quality is, similar to our approach, assessed by an aggregate disclosure index. Therefore, taking these results into account, we disaggregate the disclosure index and re-run our estimations in Specification (6). Moreover, Ahmed/Courtis (1999) cannot provide evidence on a significant relationship between firms' listing and different empirical measures of disclosure quality.

\subsubsection{Robustness checks}

In order to investigate the robustness of the primary regression results, we run three additional model specifications. First of all, as accounting requirements are different and disclosure incentives may diverge, all observations reporting net deferred tax liabilities are omitted in Specification (4) in order to avoid potential bias induced by the mandatory recognition. Accordingly, the remaining 414 firms in the subsample are exclusively faced with the decision to recognize net deferred tax assets. In line with our expectation, that it is not only the existence of temporary taxable differences, but also other motivations and incentives that underlay the heterogeneity in tax-related disclosure quality, the results are largely consistent with the previous findings in Specifications (1) - (3). That is, the coefficients on recognition and firm size as well as two measures of implementation and compliance costs (i.e. small-cap and additionally \#days) are significant, while all external monitoring variables remain insignificant.

In Specification (5), we exclude those firms that recognize deferred tax assets and liabilities in their balance sheets in order to validate that our results also hold true for nonrecognizing firms. Furthermore we want to ensure that our results are not driven by a potential correlation between the recognition variable and the dependent variable, i.e. 
the disclosure index. Again, we find significant effects for the same variables as in Specifications (1)- (3).

Moreover, as illustrated, compliance with mandatory disclosure regulations varies greatly across firms. Ahmed/Courtis (1999) provide evidence that the extent to which firms' disclosure policy is reflected in firm characteristics is highly dependent on the type of disclosure index considered. Accordingly, we re-examine our measure of disclosure quality and in Specification (6) we only take mandatory disclosure items into account. Consistent with the previous findings, the results suggest that the level of mandatory disclosure is correlated with firms' recognition of deferred taxes, size and liquidity as well as with small cap. Contradicting the findings of most previous studies, all variables of external firm monitoring remain, however, insignificant. Accordingly, we cannot provide evidence for our expectation that external monitoring efforts have a positive association with the extent of tax-related disclosure in firms' individual financial statements.

\subsubsection{Alternative model specification}

To ensure comparability with previous literature on disclosure quality, ${ }^{28}$ we also estimate an ordinary least squares (OLS) regression and run the same specifications (1)-(6) (see Table 10 in the Annex). ${ }^{29}$ The signs and significance levels of the coefficients as well as the marginal effects are strongly in line with our GLM results and therefore support our findings.

Finally as an alternative model specification, we estimate a two-boundary Tobit model to account for corner solutions (Wooldridge (2010, pp. 667)). ${ }^{30}$ Our results (see Table 11 in the Annex) again remain largely unchanged. However, in addition to the above findings, we also observe a consistent significant negative relation between disclosure quality and \#days (in all specifications apart from Specification (6)). This further supports our position that implementation and compliance costs may negatively influence firms’ reporting quality.

28 For an overview, see Chavent et al. (2006), pp. 207-214.

29 Nevertheless, we do not use OLS as our main specification since our dependent variable is bound to be between zero and one and thus we can't assume a linear relationship, in particular beyond these boundaries.

30 We do not use this approach as main model because of heteroscedasticity issues. Nevertheless, the results remain largely unchanged, given the assumptions of the Tobit model. 


\subsubsection{Further analysis: Decomposition of the reporting items of the disclosure index}

Additionally, we aim to assess whether there are differences in the determinants of the disclosure quality across the single items. Therefore we run regression specification (3) with the full set of control variables for each item separately. ${ }^{31}$ As the dependent variable is binary in this case, we use a probit model (Table 12).

First of all, the results unfold that the determinants of the aggregate score correspond to the main drivers of most of the single mandatory reporting items (item 1-3), e.g. recognition and firm_size increase the probability of reporting on those components. However, item 4 (reporting on tax loss carryforwards) reveals different incentives to some extent: First of all, a higher ETR seems to decrease the probability to report on losses with respect to deferred taxes. In addition, firms with high leverage are more likely to disclose on this item. These findings may indicate that low ETR and highly leveraged companies are more willing to provide information on this component. For companies actually reporting that they have taken tax loss carryforwards into consideration when reporting on deferred tax assets, this result could be interpreted as a signaling of positive future economic prospects. Importantly, firm_size, however, does not impact on this disclosure decision.

Regarding the voluntary disclosure items, it first of all stands out that firm_size again does not seem to be relevant. In support of our previous argumentation on the positive signaling effect of the reporting on losses, we do find that less profitable companies are more probable to provide additional quantitative information on tax loss carryforwards (items 8 and 9). Interestingly, we also find that companies which are audited by a Big 4 company are less likely to report on the voluntary disclosure items (items 7-9).

31 We do not, however, consider items 11 and 12 as all concerned corporations disclose these components, i.e. there is no variation. 


\section{Conclusion}

Building on a unique sample of 465 hand-collected individual financial statements, we find that current accounting standards governing the recognition and disclosure of income taxes are complex, but limited in information which allow for precise inferences of book-tax differences and taxable income across firms.

At the same time, it is important to note that the newly implemented disclosure requirements under Sec. 285 No. 29 HGB provide a starting point for studying the interplay between financial and tax accounting and various other aspects of corporate taxation. We take advantage of the recently adopted disclosure regulations and disaggregate deferred tax assets and liabilities in their components to shed light on the sources and magnitude of the reporting gap in Germany. The descriptive statistics reveal that Germany is far away from a one-book accounting system. In particular, differences in the recognition and measurement of provisions (mostly mandatory) as well as unused tax loss-carryforwards can be substantial in terms of their potential effect on future profits. This becomes more remarkable when the great deal of managers' discretion in reporting on deferred taxes is taken into consideration. To this end, such discretion not only creates information asymmetry between the management and external users of financial statements, but also contradicts the main intention of the BilMoG-Act to increase the information content and transparency of financial statements prepared under German GAAP. We therefore recommend to abolish the recognition option for deferred tax assets and to state the disclosure regulations on deferred taxes in the notes more precisely.

Given the substantial heterogeneity in reporting on deferred taxes, multivariate analyses were conducted to examine why some firms disclose detailed information on deferred taxes and future tax consequences, while others do not even comply with the minimum disclosure requirements of Sec. 285 No. 29 HGB. To address this question, we construct a disclosure index measuring the extent to which mandatory and voluntary items are disclosed and undertake a detailed analysis of firms' tax disclosure practice in the notes to the financial statements. In short, three key findings stand out from the analysis: First, the recognition of deferred tax assets and liabilities on the face of the balance-sheet is significantly and positively related with disclosure quality. Accordingly, this supports our recommendation to abandon the recognition option for deferred tax assets under Sec. 274 HGB aiming not only at reducing managers' discretion in accounting, but also at enhancing firms' disclosure quality in reporting on deferred taxes. Second, our results 
show that larger firms tend to provide more detailed information on deferred taxes and future taxable consequences than smaller firms. This is consistent with the more general disclosure literature and the assumption that larger firms' accounting and tax departments tend to have specific knowledge and effective communication in place. Third, the results suggest that, all else equal, high compliance and implementation costs might also explain the observed shortcomings in disclosure quality. Moreover, we find that different reporting incentives might apply if reporting on losses is assessed in isolation. To sum up, the results of this study not only have important implications for the understanding of the magnitude and sources of the reporting gap, but also for the discussion about whether and how to reform disclosure requirements under German GAAP. 


\section{References}

Ahmed, A.S. / Kilic, E. / Lobo, G. J. (2006), Does recognition versus Disclosure Matter? Evidence from Value-Relevance of Banks' Recognized and Disclosed Derivative Financial Instruments, The Accounting Review, pp. 567-588.

Ahmed, K / Courtis, J.K. (1999), Associations between corporate characteristics and disclosure level in annual reports: A meta-analysis, British Accounting Review, pp. 35-61.

Blaylock, B. / Shevlin, T. / Wilson, R.J. (2012), Tax Avoidance, Large Positive Temporary Book Tax Differences and Earnings Persistence, The Accounting Review, pp. 91-120.

Chavent, M. / Ding, Y. / Fu, L. / Stolowy, H. / Wang, H. (2006), Disclosure and determinants studies: An extension using the Divisive Clustering Method (DIV), European Accounting Review, pp. 181-218.

Cooke, T.E. (1989), Voluntary Corporate Disclosure by Swedish Companies, Journal of International Financial Management and Accounting, pp. 171-195.

Cooke, T.E. (1992), The impact of size, stock market listing and industry type of disclosure in the annual reports of Japanese listed corporations, Accounting and Business Research, pp. 229-237.

Desai, M. (2003), The divergence between book income and tax income, in: Poterba, J. (Ed.), Tax Policy and the Economy 17, MIT Press, Cambridge, pp. 169-206.

Desai, M. (2005), The degradation of reported corporate profits, Journal of Economic Perspectives, pp. 171-192.

Dhaliwal, D. S. / Gleason, C.A. Mills, L.F. (2004), Last-Chance Earnings Management: Using the Tax Expense to Meet Analysts`Forecast, Contemporary Accounting Research, pp. 431-459.

Dwenger, N. / Walch, F. (2011), Tax Losses and Firm Investment: Evidence from Tax Statistics, Working Paper Max Planck Institute for Tax Law and Public Finance.

Eng, L.L. / Mak, Y.T. (2003), Corporate governance and voluntary disclosure, Journal of Accounting and Public Policy 22, pp. 325-345.

Ettredge, M. / Johnstone, K. / Stone, M. / Wang, Q. (2011), The effects of firm size, corporate governance quality, and bad news on disclosure compliance, Review of Accounting Studies, pp. 866-889. 
Fan, J. P. H. / Wong, T.J. (2002), Corporate ownership structure and the informativeness of accounting earnings in East Asia, Journal of Accounting and Economics, pp. 401-425.

Farrar, D. / Glauber, R. (1967), Multicollineearity in Regression Analyses the Problem Revisited, Review of Economics and Statistics, pp. 92-107.

Froschhammer, M. / Haller, A. (2012), IFRS-Konvergenz im Rahmen der BilMoGErstanwendung. Eine empirische Analyse, KoR - Zeitschrift für internationale und kapitalmarktorientierte Rechnungslegung, pp. 17-25.

Giner Inchausti, A. (1997), The influence of company characteristics and accounting regulation on information disclosed by Spanish firms, European Accounting Review, pp. 45-68.

Gleason, C. A. / Mills, L. F. (2002), Materiality and Contingent Tax Liability Reporting, The Accounting Review, pp. 317-342.

Guenther, D.A. (2011), What Do We Learn From Large Book-Tax Differences?, Working Paper University of Oregon.

Gupta, S. / Newberry, K. (1997), Determinants of the Variability in Corporate Effective Tax Rates: Evidence from Longitudinal Data, Journal of Accounting and Public Policy, pp. 1-34.

Hahn, K. / Oser, P. / Breitweg, J. / Eisenhardt, P. / Kollmann, V. (2012), Latente Steuern in der Bilanzierungspraxis mittelständischer Konzerne - Ergebnisse einer empirischen Untersuchung von BDI/EY/DHBW (Teil I), Deutsches Steuerrecht, pp. 572-578.

Hahn, K. / Oser, P. / Breitweg, J. / Eisenhardt, P. / Kollmann, V. (2012), Latente Steuern in der Bilanzierungspraxis mittelständischer Konzerne - Ergebnisse einer empirischen Untersuchung von BDI/EY/DHBW (Teil II), Deutsches Steuerrecht, pp. 619-626.

Hanlon, M. (2003), What can we infer about a firm's taxable income from its financial statements?, National Tax Journal, pp. 831-863.

Hanlon, M . / Heitzman, S. (2010), A review of tax research, Journal of Accounting and Economics, pp. 127-178.

Hanlon, M. / Maydew, E. (2009), Book-tax conformity: implications for multinational firms, National Tax Journal 62, pp. 127-153. 
Hanlon, M. / Shevlin, T. (2005), Book-tax conformity for corporate income: An introduction to the issues, Tax Policy and the Economy 19, pp. 101-134.

Hassan, O. / Marston, C. (2010), Disclosure Measurement in the Empirical Accounting Literature: A Review Article, Brunel University West London Working Paper No. 10-18.

Healy, P.M ./ Palepu, K.G. (2001), Information asymmetry, corporate disclosure, and the capital markets: A review of the empirical literature, Journal of Accounting and Economics, pp. 405-440.

Herzig, N. / Briesemeister, S. / Schäperclaus, J. (2011), Von der Einheitsbilanz zur EBilanz, Der Betrieb, pp. 1-9.

Ho, S. / Wong, K.S. (2001), A study of the relationship between corporate governance structures and the extent of voluntary disclosure, Journal of International Accounting, Auditing \& Taxation 10, pp. 139-156.

Kager, R. / Schanz, D. / Niemann, R. (2011), Estimation of Tax Values Based on IFRS Information: An Analysis of German DAX30 and Austrian ATX Listed Companies, Accounting in Europe, pp. 89-123.

Keitz, I. / Wenk, M.O. / Jagosch, C. (2011), HGB-Bilanzierungspraxis nach BilMoG (Teil 1) - Eine empirische Analyse von ausgewählten Familienunternehmen, Der Betrieb, pp. 2445-2450.

Keitz, I. / Wenk, M.O. / Jagosch, C. (2011), HGB-Bilanzierungspraxis nach BilMoG (Teil 2) - Eine empirische Analyse von ausgewählten Familienunternehmen, Der Betrieb, pp. 2503-2508.

Küting, K. / Seel, C. (2009), Die Ungereimtheiten der Regelungen zu latenten Steuern im neuen Bilanzrecht, Der Betrieb, pp. 922-925.

Lang, M. / Lundholm, R. (1993), Cross-Sectional Determinants of Analyst Ratings of Corporate Disclosures, Journal of Accounting Research, pp. 246-71.

Lisowsky, P. (2009), Inferring U.S. Tax Liability from Financial Statement Information, Journal of the American Taxation Association, pp. 29-63.

Maier, M.T. / Weil, M. (2009), Latente Steuern im Einzel-und Konzernabschluss: Auswirkungen des BilMoG auf die Bilanzierungspraxis, Der Betrieb, pp. 27292736.

Manzon, G.B. / Plesko, G.A. (2002), The Relation Between Financial and Tax Reporting Measures of Income, Tax Law Review, pp. 175-214. 
Matenaer, S. (2013), Implikationen steuerlicher Risiken - Ökonomische Analyse und empirische Evidenz, Dissertation, Köln 2013.

McGill, G.A. / Outslay, E. (2004), Lost in Translation: Detecting Tax Shelter Activity in Financial Statements, National Tax Journal, pp. 739-756.

Mills, L.F. / Newberry K. / Trautman, W.B. (2002), Trends in book-income and balance sheet differences, Tax Notes, pp. 1109-1124.

Murphy, A.B. (1999), Firm Characteristics of Swiss Companies that Utilize International Accounting Standards, International Journal of Accounting, pp. 121-131.

Oser, P. / Hahn, K. / Breitweg, J / Eisenhardt, P. (2011), Das Bilanzrechtsmodernisierungsgesetz in der Praxis mittelständischer Unternehmen. Eine emprische Untersuchung der Konzernabschlüsse 2012, Stuttgart.

Papke, L.E. / Wooldridge, J.M. (1996), Econometric methods for fractional response variables with an application to 401(K) plan participation rates, Journal of Applied Econometrics, pp. 619-632.

Papke, L.E. / Wooldridge, J.M. (2008), Panel data methods for fractional response variables with application to test pass rates, Journal of Econometrics, pp.121133.

Phillips, J.D. / Pincus, M. / Rego, S.O. / Wan, H. (2004), Decomposing Changes in Deferred Tax Assets and Liabilities to Isolate Earnings Management Activities, The Journal of the American Taxation Association, pp. 43-66.

Phillips, H. (2011), Rechnungslegungspraxis nach BilMoG - Empirische Befunde zur Ausübung von Wahlrechten und Ermessensspielräumen im ersten Jahresabschluss nach neuem Bilanzrecht, Steuern und Bilanzen, pp. 203-209.

Plesko, G.A. (2003), An evaluation of alternative measures of corporate tax rates, Journal of Accounting and Economics, pp. 201-226.

Plesko, G.A. (2006), Estimates of the Magnitude of Financial and Tax Reporting Conflicts, Working Paper University of Connecticut, pp. 1-44.

Plesko, G.A. (2007), Estimates of the Magnitude of Financial and Tax Reporting Conflicts, National Bureau of Economic Research Working Paper No. 13295.

Poterba, J.M. / Rao, N.S. / Seidman, J.K. (2011), Deferred Tax Positions and Incentives for Corporate Behavior around Corporate Tax Changes, National Tax Journal, pp. 27-58. 
Prystawik, O. / Schauf, T. (2011), Steuerliche Anhangangaben nach HGB - was ist erforderlich?, Der Betrieb, pp. 313-318.

Raedy, J.S. / Seidman, J. / Shackelford, D.A. (2011), Is There Information in the Tax Footnote?, McCombs Research Paper Series No. ACC-01-11.

Rice, S. C. / Weber, D. P. (2011). How Effective is Internal Control reporting under SOX 404? Determinants of the (Non-)Disclosure of Existing Material Weaknesses, Journal of Accounting Research, pp. 811-843.

Robinson L. A. / Schmidt, A. P. (2013), Firm and investor responses to uncertain tax benefit disclosure requirements, Tuck School of Business Working Paper No. 2009-59.

Schmidt, A. P. (2006), The persistence; forecasting, and Valuation Implications of the Tax Change Components of Earnings, The Accounting Review, pp. 589-616.

Spengel, C. / Evers, M.T. / Meier, I. (2014), Transparency in Financial Reporting: Is Country-by-Country Reporting Suitable to Combat International Profit Shifting, Bulletin for International Taxation, pp. 295-303.

Tran, A.V. (2010), Can Taxable Income Be Estimated from Financial Reports of Listed Companies in Australia?, Working Paper, pp. 1-39.

Watson, A. / Shrives, P. / Marston, C. (2002), Voluntary Disclosure of Accounting Ratios in the UK, The British Accounting Review, pp. 289-313.

Wooldridge, J.M. (2010), Econometric analysis of cross section and panel data, MIT Press, Cambridge/Mass., 2.ed, 2010.

Zinn, B. (2012), Tax accounting in Germany: Empirical evidence on the relationship between financial and tax accounting and options for reform, Dissertation, Köln 2012.

Zinn, B. / Spengel, C. (2012), Book-Tax Conformity: Empirical Evidence from Germany, ZEW-Discussion Paper Nr. 12-051, Mannheim 2012. 


\section{Annex}

\section{Table 8: Correlation matrix}

\begin{tabular}{|c|c|c|c|c|c|c|c|c|c|c|c|c|}
\hline & Recognition & ETR & Firm Size & Liquidity & Profitability & Leverage & Audit-ratio & \# days & Small-cap & Big4 & Prime & $\begin{array}{r}\text { Share- } \\
\text { holding }\end{array}$ \\
\hline Recognition & 1.0000 & & & & & & & & & & & \\
\hline ETR & 0.1057 & 1.0000 & & & & & & & & & & \\
\hline Firm Size & 0.0593 & 0.0486 & 1.0000 & & & & & & & & & \\
\hline Liquidity & -0.0130 & 0.0189 & 0.0544 & 1.0000 & & & & & & & & \\
\hline Profitability & 0.0732 & -0.1593 & 0.1906 & 0.0389 & 1.0000 & & & & & & & \\
\hline Leverage & 0.0370 & 0.0270 & 0.3187 & -0.1705 & -0.1824 & 1.0000 & & & & & & \\
\hline Audit-ratio & -0.0137 & -0.0504 & -0.0670 & 0.1691 & -0.1229 & -0.1640 & 1.0000 & & & & & \\
\hline \# days & -0.0494 & 0.0472 & -0.3969 & -0.0663 & -0.4287 & 0.0509 & 0.1423 & 1.0000 & & & & \\
\hline Small-cap & -0.0551 & -0.0923 & -0.3615 & -0.0235 & -0.0147 & -0.1814 & 0.0425 & 0.1020 & 1.0000 & & & \\
\hline Big4 & 0.0111 & 0.1079 & 0.4154 & -0.0051 & 0.0162 & 0.0915 & -0.1216 & -0.2093 & -0.1865 & 1.0000 & & \\
\hline Prime & 0.0311 & 0.0209 & 0.4478 & -0.0264 & 0.0500 & 0.0189 & 0.0585 & -0.3169 & -0.1214 & 0.2207 & 1.0000 & \\
\hline $\begin{array}{l}\text { Share- } \\
\text { holding }\end{array}$ & 0.0303 & 0.0512 & -0.1303 & -0.0154 & 0.0320 & 0.0068 & -0.0460 & 0.0721 & 0.0159 & -0.0295 & -0.2362 & 1.0000 \\
\hline
\end{tabular}


Table 9: Marginal effects (GLM)

\begin{tabular}{|c|c|c|c|c|c|c|}
\hline \multirow[t]{2}{*}{ Disclosure index } & \multicolumn{4}{|c|}{ Main regressions } & \multicolumn{2}{|c|}{ Robustness test } \\
\hline & (1) & (2) & (3) & (4) & (5) & (6) \\
\hline \multicolumn{7}{|l|}{ Tax status } \\
\hline \multirow[t]{2}{*}{ Recognition } & 0.282 & 0.269 & 0.268 & 0.300 & & 0.170 \\
\hline & $(0.0227)$ & $(0.0215)$ & $(0.0216)$ & $(0.0251)$ & & $(0.0288)$ \\
\hline ETR & $(0.0421)$ & $(0.0416)$ & $(0.0414)$ & $(0.0440)$ & $(0.0541)$ & $(0.0466)$ \\
\hline \multicolumn{7}{|c|}{ General disclosure variables } \\
\hline \multirow[t]{2}{*}{ Firm size } & 0.0290 & 0.0178 & 0.0218 & 0.0211 & 0.0205 & 0.0337 \\
\hline & $(0.0057)$ & $(0.0067)$ & $(0.0077)$ & $(0.0081)$ & $(0.0093)$ & $(0.0091)$ \\
\hline Liquidity & -0.0003 & -0.0003 & -0.0003 & -0.0002 & -0.0003 & -0.0003 \\
\hline \multirow[t]{2}{*}{ PTROA } & 0.0198 & -0.0334 & -0.0478 & -0.0725 & -0.0322 & -0.0431 \\
\hline & $(0.1050)$ & $(0.1082)$ & $(0.1086)$ & $(0.1122)$ & $(0.1354)$ & $(0.1038)$ \\
\hline \multirow[t]{2}{*}{ Leverage } & 0.0570 & 0.0623 & 0.0544 & 0.0288 & 0.0460 & 0.0767 \\
\hline & $(0.0616)$ & $(0.0617)$ & $(0.0624)$ & $(0.0663)$ & $(0.0778)$ & $(0.0683)$ \\
\hline \multicolumn{7}{|c|}{ Implementation costs } \\
\hline \multirow[t]{2}{*}{ Audit intensity } & & -0.0147 & -0.0185 & -0.0413 & -0.0409 & -0.0253 \\
\hline & & $(0.0402)$ & $(0.0410)$ & $(0.0494)$ & $(0.0571)$ & $(0.0541)$ \\
\hline \multirow[t]{2}{*}{ \# days } & & -0.0008 & -0.0009 & -0.0011 & -0.0011 & -0.0006 \\
\hline & & $(0.0005)$ & $(0.0005)$ & $(0.0006)$ & $(0.0007)$ & $(0.0006)$ \\
\hline \multirow[t]{2}{*}{ Small-cap } & & -0.0590 & -0.0598 & -0.0839 & -0.0835 & -0.1032 \\
\hline & & $(0.0316)$ & $(0.0316)$ & $(0.0342)$ & $(0.0401)$ & (0.0319) \\
\hline
\end{tabular}




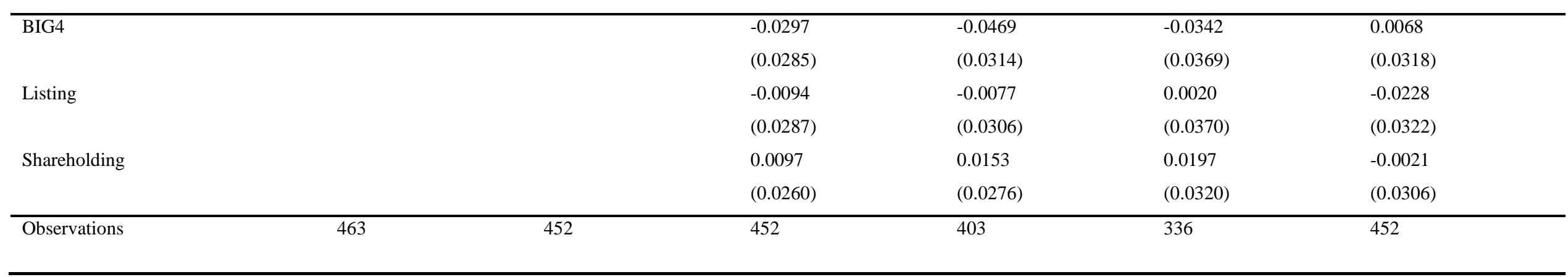

Note: In specification (4) all observation showing net deferred tax liabilities are omitted. In Specification (5) we exclude all corporations which disclose deferred taxes on the face of the balance sheet. In Specification (6) only mandatory disclosure items are taken into account. Standard errors are reported in parentheses. 
Table 10: Regression results (OLS)

\begin{tabular}{|c|c|c|c|c|c|c|}
\hline \multirow[t]{2}{*}{ Disclosure index } & \multicolumn{4}{|c|}{ Main regressions } & \multicolumn{2}{|c|}{ Robustness test } \\
\hline & (1) & (2) & (3) & (4) & (5) & (6) \\
\hline \multicolumn{7}{|l|}{ Tax status } \\
\hline \multirow[t]{2}{*}{ Recognition } & $0.283^{* * *}$ & $0.273^{* * *}$ & $0.273^{* * *}$ & $0.299 * * *$ & & $0.163^{* * *}$ \\
\hline & $(0.0231)$ & $(0.0232)$ & $(0.0234)$ & $(0.0256)$ & & $(0.0263)$ \\
\hline ETR & $(0.0425)$ & $(0.0423)$ & $(0.0424)$ & $(0.0449)$ & $(0.0550)$ & $(0.0503)$ \\
\hline \multicolumn{7}{|c|}{ General disclosure variables } \\
\hline \multirow[t]{2}{*}{ Firm size } & $0.0297 * * *$ & $0.0184^{* * *}$ & $0.0225^{* * *}$ & $0.0216^{* *}$ & $0.0212^{* *}$ & $0.0324 * * *$ \\
\hline & $(0.00582)$ & $(0.00683)$ & $(0.00795)$ & $(0.00836)$ & $(0.00961)$ & $(0.00919)$ \\
\hline Liquidity & $-0.00026 * *$ & $-0.00016^{* *}$ & $-0.00027 * *$ & -0.00023 & $-0.00029 *$ & $-0.00036 * *$ \\
\hline \multirow[t]{2}{*}{ PTROA } & 0.0198 & -0.0321 & -0.0470 & -0.0723 & -0.0352 & 0.0730 \\
\hline & $(0.101)$ & $(0.110)$ & $(0.110)$ & $(0.114)$ & $(0.132)$ & $(0.123)$ \\
\hline \multirow[t]{2}{*}{ Leverage } & 0.0582 & 0.0647 & 0.0560 & 0.0303 & 0.0480 & 0.0781 \\
\hline & $(0.0627)$ & $(0.0631)$ & $(0.0639)$ & $(0.0678)$ & $(0.0787)$ & $(0.0737)$ \\
\hline \multicolumn{7}{|c|}{ Implementation costs } \\
\hline \multirow[t]{2}{*}{ Audit intensity } & & -0.0140 & -0.0177 & -0.0403 & -0.0389 & -0.0276 \\
\hline & & $(0.0396)$ & $(0.0406)$ & $(0.0483)$ & $(0.0532)$ & $(0.0643)$ \\
\hline \multirow[t]{2}{*}{ \# days } & & -0.000787 & -0.000865 & $-0.00111^{*}$ & -0.00105 & -0.000523 \\
\hline & & $(0.000547)$ & $(0.000554)$ & $(0.000614)$ & $(0.000674)$ & $(0.000704)$ \\
\hline \multirow[t]{2}{*}{ Small-cap } & & $-0.0591 *$ & $-0.0599 *$ & $-0.0836 * *$ & $-0.0824 * *$ & $-0.116^{* * *}$ \\
\hline & & $(0.0323)$ & $(0.0324)$ & $(0.0349)$ & $(0.0402)$ & (0.0385) \\
\hline
\end{tabular}




\begin{tabular}{|c|c|c|c|c|c|c|}
\hline \multirow[t]{2}{*}{ BIG4 } & & & -0.0301 & -0.0468 & $\begin{array}{l}-0.0346 \\
\end{array}$ & 0.00715 \\
\hline & & & $(0.0291)$ & $(0.0322)$ & $(0.0379)$ & $(0.0345)$ \\
\hline \multirow[t]{2}{*}{ Listing } & & & -0.00968 & -0.00789 & -0.00143 & -0.0195 \\
\hline & & & $(0.0293)$ & $(0.0322)$ & $(0.0378)$ & $(0.0399)$ \\
\hline \multirow[t]{2}{*}{ Shareholding } & & & 0.00962 & 0.0150 & 0.0199 & -0.00183 \\
\hline & & & $(0.0266)$ & $(0.0283)$ & $(0.0326)$ & $(0.0320)$ \\
\hline $\mathrm{R}^{2}$ & 0.2677 & 0.2635 & 0.2660 & 0.2506 & 0.1128 & 0.1967 \\
\hline Observations & 463 & 452 & 452 & 403 & 336 & 452 \\
\hline
\end{tabular}

Note: In specification (4) all observation showing net deferred tax liabilities are omitted. In Specification (5) we exclude all corporations which disclose deferred taxes on the face of the balance sheet. In Specification (6) only mandatory disclosure items are taken into account. Standard errors are reported in parentheses. *, ** and *** represent significance levels at $0.10,0.05$ and 0.01 . 
Table 11: Regression results (Tobit model)

\begin{tabular}{|c|c|c|c|c|c|c|}
\hline \multirow[t]{2}{*}{ Disclosure index } & \multicolumn{4}{|c|}{ Main regressions } & \multicolumn{2}{|c|}{ Robustness test } \\
\hline & (1) & (2) & (3) & (4) & (5) & (6) \\
\hline \multicolumn{7}{|l|}{ Tax status } \\
\hline \multirow[t]{2}{*}{ Recognition } & $0.318^{* * *}$ & $0.305^{* * *}$ & $0.304 * * *$ & $0.333^{* * *}$ & & $0.219^{* * *}$ \\
\hline & $(0.0329)$ & $(0.0322)$ & $(0.0322)$ & $(0.0410)$ & & $(0.0574)$ \\
\hline ETR & $(0.0480)$ & $(0.0474)$ & $(0.0475)$ & $(0.0511)$ & $(0.0634)$ & $(0.0845)$ \\
\hline \multicolumn{7}{|c|}{ General disclosure variables } \\
\hline \multirow[t]{2}{*}{ Firm size } & $0.0378 * * *$ & $0.0223^{* *}$ & $0.0256 * * *$ & $0.0247 * *$ & $0.0235^{*}$ & $0.0565 * * *$ \\
\hline & $(0.0075)$ & $(0.0084)$ & $(0.0096)$ & $(0.0102)$ & $(0.0121)$ & $(0.0173)$ \\
\hline Liquidity & $-0.0003^{*}$ & $-0.0003^{* *}$ & $-0.0003 * *$ & $-0.0003^{*}$ & $-0.0004 *$ & $-0.0006^{* *}$ \\
\hline \multirow[t]{2}{*}{ PTROA } & 0.0272 & -0.0386 & -0.0504 & -0.0821 & -0.0150 & -0.0700 \\
\hline & $(0.0934)$ & $(0.0979)$ & $(0.0992)$ & $(0.105)$ & $(0.128)$ & $(0.175)$ \\
\hline \multirow[t]{2}{*}{ Leverage } & 0.0693 & 0.0773 & 0.0706 & 0.0454 & 0.0757 & 0.134 \\
\hline & $(0.0714)$ & $(0.0716)$ & $(0.0723)$ & $(0.0774)$ & $(0.0924)$ & $(0.128)$ \\
\hline \multicolumn{7}{|c|}{ Implementation costs } \\
\hline \multirow[t]{2}{*}{ Audit intensity } & & -0.0059 & -0.092 & -0.0291 & -0.0297 & 0.002 \\
\hline & & $(0.0563)$ & $(0.0568)$ & $(0.0638)$ & $(0.0732)$ & $(0.0101)$ \\
\hline \multirow[t]{2}{*}{ \# days } & & $-0.0009 *$ & $-0.001 *$ & $-0.00014^{* *}$ & $-0.00013^{*}$ & -0.0011 \\
\hline & & $(0.0006)$ & $(0.0006)$ & $(0.0007)$ & $(0.0008)$ & $(0.0010)$ \\
\hline \multirow[t]{2}{*}{ Small-cap } & & $-0.0824 * *$ & $-0.0831 * *$ & $-0.113 * * *$ & $-0.121 * * *$ & $-0.173 * * *$ \\
\hline & & $(0.0347)$ & $(0.0347)$ & $(0.0379)$ & $(0.0452)$ & $(0.0609)$ \\
\hline
\end{tabular}




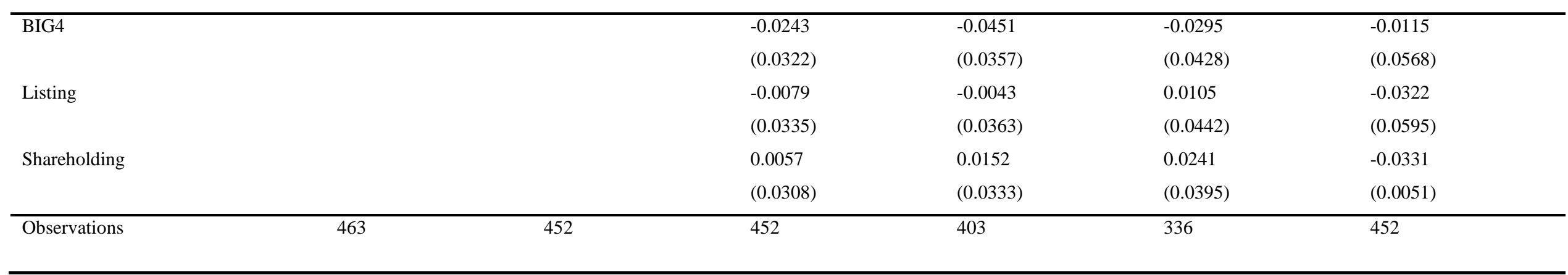

Note: In specification (4) all observation showing net deferred tax liabilities are omitted. In Specification (5) we exclude all corporations which disclose deferred taxes on the face of the balance sheet. In Specification (6) only mandatory disclosure items are taken into account. Standard errors are reported in parentheses. *, ** and $* * *$ represent significance levels at $0.10,0.05$ and 0.01 
Table 12: Regression results: Single items of disclosure index (Probit model)

\begin{tabular}{|c|c|c|c|c|c|c|c|c|c|c|}
\hline Disclosure item & (1) & (2) & (3) & (4) & (5) & (6) & (7) & (8) & (9) & (10) \\
\hline \multicolumn{11}{|l|}{ Tax status } \\
\hline \multirow[t]{2}{*}{ Recognition } & $1.594 * * *$ & $1.363^{* * *}$ & $1.160 * * *$ & $0.833^{* * *}$ & & $2.770^{* * *}$ & $0.182 * * *$ & $1.223 * * *$ & $0.625^{* * *}$ & -0.413 \\
\hline & $(0.435)$ & $(0.235)$ & $(0.203)$ & $(0.153)$ & & $(0.420)$ & $(0.147)$ & $(0.147)$ & $(0.172)$ & $(0.272)$ \\
\hline \multirow[t]{2}{*}{ ETR } & -0.407 & -0.064 & 0.102 & $-0.453 * *$ & 0.191 & 0.007 & 0.086 & -0.180 & -0.098 & 0.690 \\
\hline & $(0.262)$ & $(0.241)$ & $(0.233)$ & $(0.208)$ & $(0.440)$ & $(0.272)$ & $(0.225)$ & $(0.220)$ & $(0.268)$ & $(0.426)$ \\
\hline \multicolumn{11}{|c|}{ General disclosure variables } \\
\hline \multirow[t]{2}{*}{ Size } & $0.214^{* * *}$ & $0.188 * * *$ & $0.136^{* * *}$ & 0.035 & -0.039 & 0.011 & 0.002 & 0.012 & 0.057 & 0.051 \\
\hline & $(0.065)$ & $(0.049)$ & $(0.047)$ & $(0.042)$ & $(0.103)$ & $(0.051)$ & $(0.046)$ & $(0.045)$ & $(0.054)$ & $(0.112)$ \\
\hline \multirow[t]{2}{*}{ Liquidity } & $-0.002 *$ & -0.001 & $-0.001 *$ & -0.001 & -0.003 & -0.001 & -0.001 & -0.001 & 0.000 & -0.005 \\
\hline & $(0.001)$ & $(0.001)$ & $(0.001)$ & $(0.001)$ & $(0.002)$ & $(0.001)$ & $(0.001)$ & $(0.001)$ & $(0.001)$ & $(0.005)$ \\
\hline \multirow[t]{2}{*}{ PTROA } & 0.503 & 0.074 & 0.443 & -0.627 & 0.784 & -0.342 & -0.514 & $-0.733 *$ & $-1.207 * *$ & -1.433 \\
\hline & $(0.513)$ & $(0.431)$ & $(0.451)$ & $(0.452)$ & $(0.901)$ & $(0.508)$ & $(0.441)$ & $(0.434)$ & $(0.480)$ & $(0.913)$ \\
\hline \multirow[t]{2}{*}{ Leverage } & 0.586 & 0.176 & -0.096 & $0.822 * *$ & $-1.216^{*}$ & 0.199 & 0.006 & 0.467 & 0.468 & -1.125 \\
\hline & $(0.258)$ & $(0.354)$ & $(0.329)$ & $(0.326)$ & $(0.728)$ & $(0.398)$ & $(0.345)$ & $(0.327)$ & $(0.392)$ & $(0.712)$ \\
\hline \multicolumn{11}{|c|}{ Implementation costs } \\
\hline \multirow[t]{2}{*}{ Audit intensity } & 0.258 & $-0.509 *$ & -0.213 & -0.032 & 0.748 & 0.160 & -0.032 & -0.088 & -0.171 & -0.403 \\
\hline & $(0.404)$ & $(0.286)$ & $(0.277)$ & $(0.228)$ & $(0.682)$ & $(0.306)$ & $(0.227)$ & $(0.242)$ & $(0.239)$ & $(0.481)$ \\
\hline \multirow[t]{2}{*}{ \# days } & -0.003 & 0.000 & -0.002 & -0.004 & 0.003 & -0.006 & -0.004 & $-0.005 *$ & $-0.006 *$ & -0.009 \\
\hline & $(0.004)$ & $(0.003)$ & (0.003) & $(0.003)$ & $(0.006)$ & $(0.004)$ & $(0.003)$ & $(0.003)$ & $(0.003)$ & $(0.006)$ \\
\hline \multirow[t]{2}{*}{ Small-cap } & $0.599 * * *$ & $-0.503 * * *$ & $-0.545 * * *$ & 0.016 & -0.054 & 0.085 & -0.143 & 0.062 & 0.147 & -0.079 \\
\hline & $(0.184)$ & $(0.163)$ & $(0.158)$ & (0.153) & $(0.340)$ & (0.198) & $(0.166)$ & $(0.167)$ & (0.193) & $(0.351)$ \\
\hline
\end{tabular}




\begin{tabular}{|c|c|c|c|c|c|c|c|c|c|c|}
\hline BIG4 & $\begin{array}{l}0.219 \\
(0.185)\end{array}$ & $\begin{array}{l}-0.152 \\
(0.163)\end{array}$ & $\begin{array}{l}0.204 \\
(0.152)\end{array}$ & $\begin{array}{l}-0.159 \\
(0.145)\end{array}$ & $\begin{array}{l}0.176 \\
(0.291)\end{array}$ & $\begin{array}{l}-0.169 \\
(0.184)\end{array}$ & $\begin{array}{l}-0.283^{*} \\
(0.155)\end{array}$ & $\begin{array}{l}-0.308 * * \\
(0.150)\end{array}$ & $\begin{array}{l}-0.413^{* *} \\
(0.189)\end{array}$ & $\begin{array}{l}-0.718^{* *} \\
(0.313)\end{array}$ \\
\hline Listing & $\begin{array}{l}-0.235 \\
(0.213)\end{array}$ & $\begin{array}{l}-0.071 \\
(0.168)\end{array}$ & $\begin{array}{l}-0.007 \\
(0.158)\end{array}$ & $\begin{array}{l}-0.105 \\
(0.151)\end{array}$ & $\begin{array}{l}-0.107 \\
(0.290)\end{array}$ & $\begin{array}{l}0.023 \\
(0.290)\end{array}$ & $\begin{array}{l}-0.077 \\
(0.162)\end{array}$ & $\begin{array}{l}-0.044 \\
(0.157)\end{array}$ & $\begin{array}{l}0.057 \\
(0.195)\end{array}$ & $\begin{array}{l}-0.111 \\
(0.344)\end{array}$ \\
\hline Shareholding & $\begin{array}{l}0.171 \\
(0.186)\end{array}$ & $\begin{array}{l}0.011 \\
(0.154)\end{array}$ & $\begin{array}{l}0.187 \\
(0.150)\end{array}$ & $\begin{array}{l}-0.161 \\
(0.137)\end{array}$ & $\begin{array}{l}-0.335 \\
(0.288)\end{array}$ & $\begin{array}{l}0.108 \\
(0.169)\end{array}$ & $\begin{array}{c}0.133 \\
(0.152)\end{array}$ & $\begin{array}{l}0.043 \\
(0.147)\end{array}$ & $\begin{array}{l}0.086 \\
(0.183)\end{array}$ & $\begin{array}{l}-0.206 \\
(0.306)\end{array}$ \\
\hline Observations & 426 & 451 & 449 & 452 & 113 & 362 & 452 & 449 & 410 & 110 \\
\hline
\end{tabular}

Note: Dependent variables are as follows: (1) Disclosure of deferred taxes on the face of the balance sheet and corresponding explanations in the notes or that the corporations does not recognize net deferred tax assets; (2) Disclosure of tax rates at which deferred taxes have been measured; (3) Disclosure of temporary differences on which (un)recognized deferred taxes are based on (qualitative); (4) Disclosure that tax loss carryforwards have been taken into consideration when reporting on deferred taxes (qualitative); (5) Disclosure of tax expenses or benefits on the face of the income statements; (6) Disclosure of aggregate deferred tax assets (quantitative); (7) Disclosure of temporary differences on which (un)recognized deferred taxes are based (quantitative); (8) Disclosure of recoverable loss carryforwards (quantitative); (9) Disclosure of non-recoverable loss carryforwards (quantitative); (10) Disclosure of the different types of taxes that the loss carryforward is based on (quantitative). Standard errors are reported in parentheses. *, ** and $* * *$ represent significance levels at 0.10 , 0.05 and 0.01 . 